BGPE Discussion Paper

No. 166

\title{
The causal effect of age at migration on youth educational attainment
}

\section{Dominique Lemmermann Regina T. Riphahn}

October 2016

ISSN 1863-5733

Editor: Prof. Regina T. Riphahn, Ph.D.

Friedrich-Alexander-University Erlangen-Nuremberg

(c) Dominique Lemmermann, Regina T. Riphahn 


\title{
The causal effect of age at migration on youth educational attainment
}

\author{
Dominique Lemmermann \\ (Friedrich-Alexander University Erlangen-Nürnberg) \\ and \\ Regina T. Riphahn \\ (Friedrich-Alexander University Erlangen-Nürnberg)
}

October 28, 2016

We investigate the causal effect of age at migration on subsequent educational attainment in the destination country. To identify the causal effect we compare the educational attainment of siblings at age 21, exploiting the fact that they typically migrate at different ages within a given family. We consider several education outcomes conditional on family fixed effects. We take advantage of long running and detailed data from the German Socio-Economic Panel, which entails an oversample of immigrants and provides information on language skills. We find significant effects of age at migration on educational attainment and a critical age of migration around age 6 . The educational attainment of female immigrants responds more strongly to a high age at immigration than that of males.

JEL Code: I21, J61, C21

Keywords: immigration, education, integration, school attainment, Germany, causal estimation, family fixed effect

Correspondence to:

Regina T. Riphahn

FAU Erlangen-Nürnberg

Lange Gasse 20

90403 Nürnberg, Germany

Phone: +49 - 911 - 5302826

Fax: $\quad+49-911-5302178$

Email: regina.riphahn@fau.de

We gratefully acknowledge helpful comments by Hillel Rapoport, Katharina Wrohlich, Michael Zibrowius, and participants of the meeting of the European Association of Labour Economists 2016 (Ghent), German Economic Association 2016 (Augsburg), DFG Priority Program 1764 (Essen), seminars at the University of Maastricht, the Ruhr Graduate School in Economics, the CEMIR Junior economist workshop on migration research, the Cologne Institute for Economic Research, and the social policy group of the German Economic Association (Mannheim). 


\section{Introduction}

Most contributors to the debate of immigration agree that it is important to educate immigrating youth in order to lay the foundations for their successful future. However, the literature on immigrant education is divided on the patterns of immigrant youth educational attainment. In particular, recent studies disagree on whether there are in fact critical periods in a child's life prior to which migration should be completed to avoid permanent disadvantages.

We study the causal effect of age at migration on various education outcomes for the children of adult immigrants. The key challenge in this analysis is to account for the potentially endogenous timing of migration. Clearly, parents who are aware and mindful of their children's needs may pick particularly suitable periods in their offspring's educational career to transit to a new environment. Also, families which are able to consider their children's needs in timing migration may enjoy more favorable overall circumstances than those who are not free to choose the time of migration (e.g., highly qualified workers hired abroad vs. refugees).

We apply a sibling fixed effects approach to avoid endogeneity-induced biases in our estimations. In particular, we look at the educational attainment of first generation immigrant siblings to Germany at age 21. Typically, families move together and at the same time. Therefore, siblings within a family move at different ages. By comparing such siblings' educational attainment conditional on family fixed effects, we identify the causal effect of age at migration and account for heterogeneities based on, e.g., immigrant cohort and reason for immigration, cultural and linguistic background, neighborhood characteristics, or family-level characteristics such as parental ability, preferences and wealth. It is important to note that empirically the effect of age at migration cannot be distinguished from the effect of host country experience; therefore, we follow the literature (Böhlmark 2008, van den Berg et al. 2014) and consider the combined effect.

A large literature argues that the educational attainment of immigrants benefits from a longer experience of the destination country environment: first, youths who start earlier to 
acquire a foreign language and who have more time to do so should be more successful in mastering that language; knowledge of the host country language likely affects education outcomes. ${ }^{1}$ Second, migration might cause stress which may affect educational performance less if it is experienced at an earlier rather than later age. Finally, those with more time to assimilate to a new culture, with longer exposure to the new institutional framework, and with more years of education in the host country plausibly benefit compared to those migrating at an advanced age. ${ }^{2}$ From a theoretical perspective the effect of age at migration can be considered as one element in the "technology of skill formation" for immigrants; in this case it is immediately plausible that human capital investments at different ages are no perfect substitutes and that there might exist critical periods of investment (Cunha and Heckman 2007).

Prior contributions on the causal effects of age at immigration focused on the existence of critical periods in child development. Gjefsen and Galloway (2013) use sibling fixed effects models to study education outcomes in Norway. They find a gradual decline in school grades with increasing age at migration and do not find critical ages of migration. In contrast, van den Berg et al. (2014), who study adult outcomes of immigrants in Sweden, find that living conditions are particularly important just prior to the onset of puberty around age 9. Migration after that critical age may expose children to detrimental effects on a number of subsequent outcomes. This confirms Böhlmark's (2008) findings also on Swedish data who studied school grades of male and female migrants. He concludes that if immigrants arrive by age 9 , they may be able to catch up to their native peers whereas migration at a later age impairs the performance of girls and boys. ${ }^{3}$

\footnotetext{
1 Some authors exploit the effect of age at migration on language skills in instrumental variable frameworks to identify the effect of language acquisition on other outcomes (e.g., Guven and Islam 2015, Bleakley and Chin 2004, 2010).

2 See e.g., Cobb-Clark et al. (2012), Beck et al. (2012), Corak (2012), Schaafsma and Sweetman (2001), Böhlmark (2009), or Colding et al. (2009).

3 Åslund et al. (2009, 2015) use family fixed effects in their study of later life outcomes of immigrants to Sweden as a function of age at arrival. They point to general negative effects of late arrival but do not specifically discuss critical ages. In a correlation study for 45,000 immigrants to Israel Cahan et al. (2001) find age 7 to be a critical age for scholastic achievement.
} 
Due to cultural and biological differences, age at migration might affect male and female immigrants differently. Nevertheless, causal evidence on gender differences is scarce and heterogeneous. Böhlmark (2008) finds similar effects of age at migration on school performance for male and female immigrants. Female immigrants appear to perform better, especially for younger immigration age groups, but these gender differences are mostly insignificant. Åslund et al. (2009) find substantially larger age at migration effects on educational attainment for females than for males. Also, Gjefsen and Galloway (2013) observe that female immigrants respond stronger to late arrivals than males. This is confirmed only for higher ages at migration and the education outcomes in van den Berg et al. (2014). In sum, the results regarding gender differences are inconclusive.

All prior studies which applied family fixed effects to identify the causal effect of age at migration on immigrant outcomes discuss the importance of acquiring foreign language skills for subsequent success in the education system and the labor market (see Böhlmark 2008, Gjefsen and Galloway 2013, Åslund et al. 2009, and van den Berg 2014). However, none of these studies is able to test the connection between age at migration, language acquisition and education outcomes. We contribute to filling this gap in the literature.

It is of substantial policy relevance to study the determinants of immigrant educational attainment and to single out and quantify the causal effect of age at migration as a mechanism. Until today, immigrants in many industrialized countries are less successful than their native peers with respect to educational attainment (OECD 2012, Algan et al. 2010). Also, if there is a critical age of migration it is important to know it. On the one hand, the information can inform parental migration choices. On the other hand, state support for immigrants can be designed more effectively when the most vulnerable groups, e.g., by age and sex, can be identified. So far, evidence on the critical age of migration is available only for the case of Scandinavia. It is important and interesting to consider other countries with similar migration histories but different education systems. 
This paper contributes to the literature in several ways. First, we improve on prior studies as we consider sibling pairs at an exact identical age (we look at age 21). This should more reliably identify the effect of age at migration then if we compare family members at different ages, e.g., when they reach an objective such as high school graduation. Second, we pay attention to gender differences and offer a substantial set of robustness tests for our analyses. Third, in contrast to the prior literature which used Scandinavian register data, our survey based analysis allows us to study the relevance of mechanisms such as health and - more importantly - language ability for the causal effect of age at migration on educational attainment. Finally, we address the German case where educational institutions differ from Scandinavian countries while immigration histories are comparable. Also, in view of the recent refugee crisis the German case is of particular relevance.

We obtain the following results: graphical and least squares regression analyses yield significant correlations of age at migration with education outcomes. Once we control for family fixed effects and thus account for the potential endogeneity of age at migration, the correlations observed in the least squares analysis generally increase and are estimated more precisely. In contrast to the evidence from Sweden, we find ages 5-6 to represent critical ages at migration: individuals arriving afterwards face significantly higher propensities of low educational attainment, such as no secondary degree or no more than a lower secondary school degree. Overall, educational attainment of males appears to respond less to age at migration than that of females. Finally, we find that language skills may not be central for the causal connection between age at migration and educational attainment.

The structure of this paper is as follows: section two briefly reviews the recent immigration history and schooling system of Germany. In section three, we present the empirical approach and discuss threats to the identification of causal effects. After a description of the data, we show our main results in section four. Section five presents a broad set of robustness checks and we conclude in section six. 


\section{Historical and Institutional Background}

\subsection{A brief review of five decades of immigration to Germany}

In the first years after World War II West Germany absorbed several million refugees from former German territories and Eastern Europe (for details see e.g., Bauer et al. 2013). In addition, about 2.6 million individuals migrated from East to West Germany before the construction of the Berlin Wall in 1961. Between 1960 and 1973 West Germany recruited "guestworkers" mostly from Italy, Spain, Greece, Turkey, Portugal, and Yugoslavia, predominantly low-skill, blue-collar workers. By the time the recruitment stopped, the foreignborn population in West Germany had grown from 0.7 in 1961 to 4.1 million in 1973. In the seventies and eighties, many guestworkers brought their families to Germany and only few returned to their home countries.

Immediately after 1989, ethnic Germans from Eastern Europe, asylum seekers, and refugees from the Balkans dominated immigration. In 2000, the government liberalized naturalization such that many long-time foreign residents took up German citizenship. After low net immigration in the early 2000s, immigration has been rising since 2007 when citizens of new EU member countries (e.g., Poland, Romania, Bulgaria) increasingly took up residence in Germany (e.g., BAMF 2014). Recently, the number of asylum requests increased from 127,023 in 2013, and 476,649 in 2015. The total number of inflowing refugees for 2015 is estimated to be around 1.1 million (see BMI 2016).

The composition and characteristics of the immigrant population changed over time. While guestworkers mainly came to work in blue collar jobs and carried little formal education more recent immigrants are on average better qualified than the native population (Bonin 2014). Also, the immigrants' countries of origin shifted over time. Whereas a large share of guestworker immigrants originated in Turkey most recently Poland, Romania, and Bulgaria dominated as countries of origin (BAMF 2014). 


\subsection{Educational institutions in Germany}

After typically 4 years in primary school, at age 10 pupils move on to one out of three tracks (e.g., Heineck and Riphahn 2009, KMK 2014): lower secondary school (Hauptschule) lasts another 6 years and prepares for vocational training. Secondary school (Realschule/Mittelschule) also provides 6 years of instruction and typically prepares for training in white collar occupations. Upper secondary school (Gymnasium) continues for an additional 8 or 9 years. The upper secondary school degree (Abitur) is required for university admission. ${ }^{4}$ Once pupils leave secondary school, they can choose different pathways. Those with an upper secondary school degree can take up academic studies. Generally, however, a transition into vocational training has been most common. It is possible for graduates from all tracks. The German vocational training system offers apprenticeships, which combine school and firm based training and fulltime schooling without firm involvement. Finally, there are programs that improve applicants' qualifications but do not grant vocational degrees.

Over the last decades, the German secondary education system underwent a substantial expansion. Whereas no more than 10 percent of the 1920-1940 birth cohorts attained upper secondary education degrees, this share increased and now reaches above 50 percent of a birth cohort (see AB 2014a). We observe a large gap in educational attainment for natives and immigrants and their descendants. In particular, the probability of high school dropout is twice as high among immigrants (5.8 percent) than among natives (2.5 percent) (AB 2014b). Similarly, the share of individuals at age 20-25 who obtained an upper secondary school degree is lower for immigrants than for natives (38.7 vs. 45.7 percent). Among immigrants aged 2025, females have a slightly higher probability of dropout ( 0.5 percentage point) compared to males, but enjoy a higher probability of attaining an upper secondary degree. Gender differences are comparable in size and direction for natives and immigrants (AB 2014b).

\footnotetext{
$4 \quad$ Also, comprehensive schools (Gesamtschule) grant degrees of either track. As the German education system is administered at the level of the federal states, some institutional details vary by state.
} 


\section{Empirical Approach and Data}

\subsection{Identification of causal effects}

We intend to estimate the causal effect of age at migration on subsequent education outcomes. As unobservables may be correlated with both the age at migration and subsequent educational attainment, we have to account for the potential endogeneity of the treatment. This potential endogeneity may derive from several mechanisms. These mechanisms can be individual- and family-specific and they can be constant or time-varying. Since the age of migration is most likely not determined by the youth but the parents, it appears that individual-specific unobservables should be less relevant than unobservables at the level of family and parents. To account for the latter we follow the literature (e.g., Böhlmark 2008 and van den Berg et al. 2014) and apply a sibling fixed effects approach. Our baseline model is

$$
Y_{i}=\beta_{0}+\beta_{1} A_{A M}+\beta_{2} \text { firstborn }_{i}+\beta_{3} \text { female }_{i}+\beta_{4} \text { year of migration } i+\text { sfe }_{j}+e_{1 i} \text {, }
$$

where $\mathrm{Y}$ represents an education outcome for individual i. AAM indicates the age at migration for individual i. $\beta_{0}-\beta_{4}$ are the parameters to be estimated, $e_{1 i}$ is a white noise error term. Further control variables include an indicator for being firstborn, female, and year of migration in order to account for different education outcomes by parity and gender. The control for year of immigration both accounts for trends in immigrant characteristics over time and for the within family sequence of migration. We consider sibling fixed effects (sfe) to account for unobservables that characterize family $\mathrm{j}$ and do not change over time (e.g., year and reason of migration, selection into no-return migration, parental characteristics such as ability, ambition for their children, preferences and wealth, genetic endowment, citizenship, cultural and linguistic background including the quality of home country education, neighborhood characteristics, state-level characteristics of the education system and the quality of schooling). The fixed effect also accounts for any selectivity of the sample and the considered time period 
as long as these mechanisms are constant. In order to investigate gender-specific patterns of age at migration effects we consider a model with interaction terms of AAM and the male and female indicators:

$$
\begin{aligned}
Y_{i}=\gamma_{0}+\gamma_{1}\left(\text { AAM }^{*} \text { female }_{i}\right. & +\gamma_{2}\left(\text { AAM }^{*} \text { male }\right)_{i}+\gamma_{3} \text { firstborn }_{i}+\gamma_{4} \text { female }_{i} \\
& +\gamma_{5} \text { year of migration }_{i}+\text { sfe }_{j}+e_{2 i} .
\end{aligned}
$$

Again, $\gamma_{0}-\gamma_{5}$ are parameters to be estimated, $\mathrm{e}_{2 \mathrm{i}}$ is a white noise error term. Models (1) and (2) identify the causal effect if the sibling fixed effects controls for all omitted variables that might otherwise render age at migration endogenous to youth education outcomes. We control for any age-related outcome differences by considering siblings at exactly the same age. We use the same identifying assumption as Böhlmark (2008), i.e., that conditional on the covariates older and younger siblings would have attained the same education outcomes without migration.

Several mechanisms may threaten our identification approach: first, if educational possibilities for a subset of children in the home country (e.g., for sons only) induce the migration decision then there are individual-specific heterogeneities that the sibling fixed effect cannot account for. We take account of such patterns by controlling for observable outcome heterogeneities such as by gender. Furthermore, we test more specifically whether the causal effect of interest differs by gender. To address the problem of potential child specific unobservables we restrict the sample to families where all children migrated exactly in the same calendar year as opposed to a window of five years. When all children migrate at the same time it is less likely that the age at migration is endogenously determined at an individual level.

Second, because age at migration is correlated with birth order we are not able to separately identify age at migration vs., e.g., being the oldest child in our family fixed effects setting. If, in general, the education outcomes of firstborn children are better than those of their younger siblings this will attenuate the (expected negative) age at migration effect as the first 
born by definition migrate at the oldest age. Also, younger children might benefit from having older siblings in an unknown environment. This might generate an upward bias in the age at migration effect as the later born siblings enjoy additional support. We generally address this concern by always controlling for the firstborn status of children. In addition, we consider robustness tests where we include interaction terms of firstborn with age at migration and a full set of child parity indicators to evaluate whether there are significant birth order effects in educational attainment.

Third, the education expansion over the last decades may affect estimates if the young have an easier time to enter advanced schooling than their older siblings due to a secular drift in outcomes. In that situation, a negative age at migration effect would be overestimated. However, we account for such effects by controlling for the calendar year of immigration.

Fourth, since typically children immigrate with their parents the effect of age at immigration cannot be separated from the parental experience in the host country. This issue can be addressed by changing the control group from, e.g., the youngest immigrating children to those who were born after migration in the host country. By considering first and second generation immigrants we can separately account for the effect of parental time in the host country using the children born in the host country. We compare the age at migration effect obtained within our sample of first generation immigrants to that derived from a comparison with children born in the destination country with heterogeneus parental years since migration. If the estimation results for first generation immigrants hold up when we account for parental years since migration using second generation children, then parental time in the host country is not the key mechanism behind the age at migration effect for first generation migrants.

One further mechanism might bias our results. If parents initially intended to return to the home country they may initiate investments in host country specific human capital only with delay. This then causes a disadvantage for the oldest children and an upward bias on the age at migration effect. Similar biases may result from naturalization regulations. If younger 
children have better opportunities to attain citizenship in the host country (e.g., due to a longer duration of stay when reaching legal age) that may be one of the mechanisms affecting human capital investments and it might bias a "pure" age at migration effect (Felfe and Saurer 2014).

\subsection{Data description}

We use data from the German Socio-Economic Panel (SOEP 2014, Wagner et al. 2007) (19842013). The SOEP is particularly suitable for our analysis because it provides a long observation period, an oversample of immigrants, and detailed information on family background. It allows us to observe and link members of a given immigrant family across different calendar years when each of a group of siblings reached age $21 .^{5}$

We follow the literature and study the foreign-born children of migrants, i.e., with at least one parent who was not born in Germany (cf. Böhlmark 2008, van den Berg et al. 2014 or Åslund et al. 2009). Our analysis sample considers 21-year old foreign-born immigrant youths who migrated to Germany between age 0 and 17 . If children moved after that age, we cannot be sure whether they moved with their family or whether they may have migrated to live with a partner. We exclude first generation immigrant children without foreign-born siblings and omit observations on children who did not complete their secondary education by age $21 .^{6}$

We consider siblings to be children who originally lived in the same household and who have migrated within a five-year time window at the most. ${ }^{7}$ We limit the age difference between the oldest and the youngest sibling to be at most 12 years to ensure that we are not comparing parent-child pairs. Due to the fixed effects approach, our final data set does not include only

\footnotetext{
5 This matching of observations is not possible with cross-sectional data such as the German Microcensus Survey.

$6 \quad$ Once we drop these observations $(\mathrm{N}=13)$ we lose families with no more than two children in our fixed effects estimation. In our sample, all children without a secondary education degree at age 21 do not have more than one sibling. Therefore, we lose their entire family by dropping the individual observations. In a robustness test, we evaluate whether this affects our results.

7 In a robustness test, we show that limiting immigration to the same year leads to very similar results, but reduces the sample size. Similarly, we show that matching siblings based on having the same mother does not change the results.
} 
children. In addition, we cannot use children with missing information (e.g., on the type of the highest educational degree) and those whose siblings are not observed at age $21 .^{8}$ The final sample includes 348 individuals who were born between 1963 and 1990 and migrated between 1966 and $1996 .^{9}$

We consider four dependent variables describing individuals' secondary schooling degree at age 21: first, whether an individual failed to obtain a secondary educational degree at age 21 (no sec. degree), second, whether no more than a lower secondary degree was obtained (up to lower sec. degree), third, whether an upper secondary degree was attained, and fourth, total years of education, which combines school and vocational education. All indicators combine information on education obtained in the home- and host-country. In a robustness test, we evaluate whether this affects our results.

Table 1 describes the four outcome variables for different subsamples. We observe that 73.3\% of the migrant sample leave school with no more than a basic secondary degree. This includes $13.8 \%$ of young adults who do not achieve any secondary degree. In contrast, $5.2 \%$ of the migrants attain an upper secondary school degree. Immigrants attend school for 9.71 years on average. A substantially higher share of females than males remains without a school leaving certificate. At the same time, however, a higher share of females obtains an upper secondary school (Abitur) degree. Immigrants from non-European countries - despite their high age at migration - perform best, while Turkish immigrants are least successful in achieving an upper secondary degree. In our estimations, the fixed effects capture country-of-origin differences.

Our main explanatory variable of interest is age at migration. In order to generate robust and reliable conclusions that are independent of parametrization, we operationalize this measure

\footnotetext{
$8 \quad$ We omit 38 observations due to the lack of precise information on their highest educational degree from the home country (they indicated to hold an "other" degree). Interestingly, 9 of these individuals migrated prior to age 10 and another 11 prior to age 15 . In a robustness test, we evaluate whether omitting these observations affects our results.

9 These individuals originate in 145 different families of which we observe 102 with two children, 30 with three children, 11 with four children, and two with five children.
} 
in three different ways: first, we consider a linear age at migration term, second, we additionally control for a quadratic term. Third, we use indicators for six migration age groups where the age group 0-2 is the reference. Table $\mathbf{A . 1}$ in the appendix presents descriptive statistics on our covariates for the full sample and by gender.

\section{Results}

\subsection{Descriptive results}

In Figures 1.1-1.4, we present graphical evidence on the patterns of interest for each of the four outcomes, separately for male and female migrants. Figure 1.1 describes the sample shares without a secondary school degree by age at immigration. The dashed line represents the respective shares in the native population at age $21 .{ }^{10}$ The share of 21 -year olds without a degree is on average higher among immigrants than among natives. As expected, the slope in age at migration is positive for men (left panel) but surprisingly negative for women (right panel). Figure 1.2 depicts the outcome 'up to lower secondary education' with positive slopes in age at migration for male and female migrants. For the outcomes in Figures 1.3 and 1.4, i.e., 'upper secondary degree' and 'years of education', we expect negative slopes in age at migration and lower levels for immigrants than natives. While the latter is clearly confirmed the gradients are rather flat. Also, women seem to respond more strongly to age at migration than men.

Next, Table 2 presents least squares estimation results when education outcomes are regressed on three different specifications of age at migration. In Panels A and B, we consider linear and quadratic age at migration effects, while Panel C shows age-group effects with migration at age 0-2 as reference. The bottom rows in Panels B and C present the p-values of F-Tests on the joint significance of all age at migration indicators in the specification. The

10 We calculate mean values for natives with the SOEP using the same sampling criteria as for immigrants, i.e., 21-year-old German siblings, observed between 1984 and 2013. 
regressions control for female, firstborn, region of origin, parental education, year of immigration, federal state, and a constant.

Overall, we find patterns that match expectations: the linear age at migration terms (see Panel A) are positively correlated with low educational attainment (columns 1 and 2) and negatively correlated with high educational attainment (columns 3 and 4) with only one of four estimates being statistically significant. We generally find jointly statistically significant quadratic age at migration effects. In Panel B, the marginal effect of age at migration at the sample mean of 8.5 years is positive in columns 1 and 2 and negative in columns 3 and 4 . This confirms the estimates in Panel A and our expectation that a higher age at migration is correlated with lower educational attainment. Finally, the coefficients in Panel C show a higher propensity for low education outcomes with higher age at migration (columns 1 and 2) and a higher propensity for high education outcomes with lower age at migration (columns 3 and 4). While individual coefficients are often not statistically significant, we obtain joint statistical significance in columns 2 and 4. Overall, the estimates match the expectation that earlier migration goes along with better education outcomes as suggested by Figures 1.1-1.4. ${ }^{11}$

\subsection{Baseline fixed effects estimation results}

Table 3 presents sibling fixed effects estimates, which account for the potential endogeneity of age at migration and yield the causal effect of age at migration on educational attainment. The coefficient estimates for the linear age at migration terms in Panel A are substantially larger than those in Table 2. Nevertheless, statistical significance results only for the outcome in column 2, 'up to lower secondary degree.' Early migration generates better education outcomes.

11 The estimations in Table 2 use the sample of the fixed effects analysis. The results are robust to using a full sample $(\mathrm{N}=778)$, which considers all first generation immigrants independent of whether a sibling is observed in the data. See Table A.2 in the Appendix. 
The results in Panel B confirm this finding again with only one out of four sets of estimates being jointly statistically significant (see p-values in the bottom row).

The estimates of the categorical age at migration indicators in Panel $\mathrm{C}$ show beneficial effects of early migration. Almost all coefficient estimates are jointly and individually statistically significant. Immigrating at age 15 vs. age 1 increases the risk of not graduating from secondary school by 47 percentage points and reduces the number of years of education by almost 2 . Since these estimates are much larger than the least squares estimates family fixed effects appear to be relevant and may have biased the estimates in Table 2 downwards. Overall, the results of the fixed effects estimations indicate that later migration causes lower education outcomes. We find the largest 'jump' in values for migration at age 3-5 vs. 6-8. ${ }^{12}$

Åslund et al. (2009) provide coefficient estimates for linear age at migration effects for their Swedish sample. Their estimations suggest that compared to those immigrating at age zero arriving to Sweden ten years later reduces expected years of schooling by 0.2 years. Our estimates in Panel A suggest much larger reductions of about 0.7 years. Van den Berg et al. (2014) also find larger effects than Åslund et al. (2009) when estimating the effects of individual age categories: immigrating at age 10 as opposed to being born in Sweden reduces years of schooling by 0.37 and 0.52 years for males and females, respectively. These authors find even larger effects at higher ages of migration. Thus, our estimates are in line with prior findings.

The international literature posits a critical age at migration: Böhlmark (2008) finds substantially increased negative school performance effects if migration occured after age 9. With respect to adult height, van den Berg et al. (2014) find a first critical age of migration around age 5 and a second more substantial effect around age 9. Guven and Islam (2015) focus on the acquisition of language skills and find that age 11 is decisive for English language skills among adult immigrants.

12 Alternative specifications of the age at migration effect (e.g., third order polynomials or wider categories) generally confirm these findings. 
Our sample sizes are too small to consider each possible age at migration separately. As the results of our categorical specification in Panel C are rather imprecise, we pursue a different estimation strategy to investigate the age patterns in greater detail: in separate estimations we consider indicators of 'migration occurred at age x or later', where x runs from 0 to 17 thereby implying a sequential adjustment of the reference group. We depict the estimated coefficients and their statistical significance for each age and outcome in Figure 2.

The results yield interesting patterns. Most coefficient estimates are positive suggesting that later migration increases the probability of attaining low education outcomes. In addition, the impact of age at migration declines with increasing ages as the coefficients tend closer to zero. This suggests that the marginal effect of migrating one year later declines when the child ages. The pattern agrees with the international literature on human capital formation and the role of dynamic complementarities (e.g., Cunha and Heckman 2007, 2009): early learning can support later learning.

We observe statistically significant coefficients in the age range 3 to 7 - with the exception of one large negative effect at age 1 which we disregard. In terms of magnitude and significance age at migration appears to have the largest effect on the propensity to attain no more than a lower secondary degree. The effects are largest at ages 5 and 6 . If children arrive in Germany at age 5 to 6 or older, the propensity to attain no more than lower secondary degree increases statistically significantly by about 20 to 24 percentage points. For children arriving after age 7 delayed migration no longer makes a statistically significant difference in their educational attainment.

\subsection{Gender differences}

Figures 1.1-1.4 suggest that there might be significant gender differences in the causal effect of age at migration. We modify our fixed effects model to test the statistical significance of age at migration effects for male and female youths, separately. We consider the set of age at 
migration indicators used in Tables 2 and $\mathbf{3}$ and interact it with both, a male and a female indicator variable (see equation 2). This specification allows us to test symmetric hypotheses for both genders in the same model. We apply this particular specification because we would lose all mixed gender sibling pairs in the sibling fixed effects estimation were we to estimate separate regressions by gender (we show a robustness test below).

Table 4 shows the estimation results again using three different age at migration specifications. The main effect for gender differences indicates that generally and on average females are less likely to have low and more likely to have high education outcomes. The estimates for the linear age at migration term in Panel A show that generally females respond stronger to a later age at migration than males: in three out of four cases the estimates are larger and the level of statistical significance is higher for females than for males. The same pattern holds in Panel B; while some of the coefficients are individually significant, the joint tests mostly do not reject the null hypotheses. Finally, the F-Tests in Panel C confirm that age at migration matters more for education outcomes of female than male migrants. Also, in almost all cases the point estimates are larger for the female subsample. The results suggest that the difference between home and host country culture and environment affects females' educational attainment more strongly than males', which appears plausible (cf. van Ours and Veenman $(2006))^{13}$

In order to test whether the gender difference in age at migration effect is robust, we repeat our estimations with a pooled sample of first and second generation immigrants separately for female and male siblings. The results (see Table A.4 in the Appendix) confirm

\footnotetext{
13 We repeated the analysis in Table 4 separately for migrants from Turkey vs. other countries. The results for both subsamples confirm that female educational attainment responds more strongly to age at migration (see Table A.3 in the Appendix). We also estimated the gender-specific age at migration effects separately by parental educational background, for different regions of origin, and for countries of origin with high vs. low female labor force participation. All estimations were performed for first generation immigrants only and for a pooled sample of first and second generation immigrants. There are no clear differences in the results by subgroups. Our results are also robust to adding interaction effects of gender and firstborn to the model in Table 4.
} 
prior results: the age at migration effects are generally substantially larger for the female sample (here identified relative to German-born immigrants).

These results agree with those of Gjefsen and Galloway (2013) for gender differences in Norway. Similarly, the Swedish studies find larger effects for females than males: Åslund et al. (2009, see Table 4) obtain coefficient estimates of -0.015 for males and of -0.023 for females when comparing first and second generation immigrants. Van den Berg et al. (2014, see Table 3) find evidence for higher sensitivity of female compared to male educational attainment only for migration at older ages. For migration before age 8 there are no clear gender differences.

To estimate gender-specific critical ages we repeated the analysis of Figure 2 separately for the male and female subsamples (see Figures 3.1 and 3.2). The magnitude of the marginal effects is larger for females than for males and we obtain more statistically significant estimates for the female subsample. The overall conclusion of Figure $\mathbf{2}$ is confirmed: except for a large insignificant estimate for males at age 0 the largest and most significant estimates are obtained in the age range between 3 and 6 years. However, overall the critical age in our data is below age 9, which was found for the case of Sweden (e.g., Böhlmark 2008).

\subsection{Transmission Mechanism: Health, Language, Life Satisfaction, Integration}

Our results suggest that age at migration determines first generation immigrants' education outcomes. We investigate three mechanisms that might determine this effect. First, we follow van den Berg et al. (2014) and consider immigrant health. The authors show that a later age at migration to Sweden causes worse health outcomes regarding height and mental health. Given that health may affect educational attainment, we test whether such a transmission mechanism exists in our data. Second, Böhlmark (2008) argues that host country language skills may be decisive for educational attainment after migration and depend on age at migration. As we have indicators for language skills, we can test whether there is support for such a mechanism. Third, we consider life satisfaction as a transmission mechanism: high life satisfaction may indicate 
the absence of depression and the subjective level of well-being. Finally, we evaluate the relevance of individual integration in the host country society: those with large German networks and without the intention of return-migration may adjust faster and have steeper improvements in educational attainment by age at migration.

We start out by investigating the correlation between age at migration and the intermediating outcomes in Figures 4.1-4.5. The satisfaction measures are coded 0-10. For language skills, the data separately informs on oral and written skill in German coded on a scale between 1 and 5. In Figure 4.2, we use the average value of both measures. The depiction yields a steep slope for the language measure. Having contact to natives and the intention to stay are both measured as indicator variables valued 1 if the person has German friends or intends to stay in Germany. We observe that immigration at an older age is correlated with fewer German friends and a lower average intention to stay.

Next, we investigate whether age at migration affects these intervening outcomes. We applied our sibling fixed effects regression models to the five dependent variables, again using linear, quadratic, and categorical age at migration indicators and controlling for female, firstborn, and year of immigration. Table A.5 shows the coefficient estimates and the results of joint F-Tests. We observe no evidence of causal age at migration effects on health, life satisfaction, and integration but clear and significant effects on language skills: late migration causes low language skills. While the entire literature claims the existence of this effect, we are among the few contributions, which can actually show it.

Given the connection between language skills and age at migration, we now estimate the causal effect of age at migration on education controlling for language skills. Table 5 shows the estimation results where we allow for a detailed representation and consider four separate language indicators as described in Table A.1: the coefficients of language skills are sometimes jointly statistically significant and always show the expected patterns. At the same time the age 
at migration effects remain robust even when language skills are controlled for. ${ }^{14}$ This suggests

first, that language skills matter for educational attainment, but may not be the key driver of the connection between age at migration and educational attainment. ${ }^{15}$

\section{Robustness Checks}

We provide four groups of robustness checks to investigate the potential threats to identification and to analyze the heterogeneity of our results.

First, we modify the reference group: instead of comparing first generation immigrants who migrated at a later age to those who migrated at age 0 - 2 we now consider second generation immigrants who were born in Germany as the reference group. The new sample consists of 1,006 individuals, 419 migrants and 587 German born children of immigrants. ${ }^{16}$ In these estimations, we do not control for year of immigration because the value does not exist for second generation immigrants. Table 6 shows sibling fixed effects estimation results for the extended sample. The coefficients of the linear age at migration terms (see Panel A) are significant for all dependent variables, except for upper secondary degree; compared to Table 3 some coefficients increase some decrease in magnitude. The signs of the coefficients match expectations and prior results appear to be robust to using the new reference group. Similarly, in Panel B the statistical significance increased relative to Table 3 and the coefficient estimates for the quadratic age at migration effect are comparable. The estimates in Panel $\mathrm{C}$ are

$14 \quad$ Formally, language skills are a 'bad control' in our model (see Angrist and Pischke 2009). This implies that the estimates of the age migration effects are downward biased when language controls are considered. Given that even the attenuated coefficient estimates are still of the same sign and at least marginally significant we interpret our results as a confirmation of the age at migration effect.

15 We obtain the same robust results for the age at migration regressors when we specify the language information in different ways, e.g., separate identifiers for writing and oral language ability or mean values. We also considered language indicators measured at age 18 or 19 instead of age 21, with robust results. - We also tested the relevance of health, life satisfaction, having native friends, and intention to stay in the education regressions. We obtain statistically insignificant coefficient estimates for these indicators. The age at migration estimates are robust to the additional controls.

16 The number of first generation immigrants increases because we can now consider families with only one migrating child and one or more children born in the host countries. These families were previously excluded. 
individually significant for later age at migration categories. Here, we find jointly significant effects of childhood migration for all dependent variables except for upper secondary degree.

We also replicated the separate estimation of the male and female subsample effects with the extended sample: Table A.6 shows the p-values of F-tests for joint significance of gender-specific age at migration effects for the three panels. Similar to Table 4 we find significant effects for immigrated females in almost all estimations and only a few significant effects for males. Overall, the results based on the extended sample corroborate the original findings. This suggests that it is indeed the child's presence in the host country which matters and not parental information or experience. ${ }^{17}$

In our second set of tests, we address the concern that child-specific unobservables might bias the estimations. First, we consider only those siblings, who migrated in the exact same calendar year, thereby excluding migration events that might have been chosen in the interest of any one specific child. Table 7 presents the results. Even though the sample size declines substantially compared to the sample used in Table 3 the coefficient estimates are in part even larger, which suggests that our baseline estimates are at worst downward biased.

As one might expect that parents attend to the needs of their firstborn children when they time their migration, we investigate next whether firstborn children experience different age of migration effects. If there are significant benefits for firstborn children families might time their migration in the interest of their oldest children, i.e., there may be child-specific unobservables, which may threaten the validity of our identification strategy. Table 8 shows the results: after controlling for separate firstborn interaction terms of age at migration we continue to find the negative age at migration effects on educational attainment for all four

17 In alternative specifications, we consider year of immigration controls using maternal year of immigration minus year of birth for second generation immigrants. The results are robust, the age at immigration estimates do not change (see appendix Table A.7). 
outcomes. In Panels A and B neither the firstborn main effects nor the interaction terms indicate significantly different patterns for firstborns. The main effects of the firstborn indicator are statistically significant in Panel C, where they suggest in general a lower propensity of the firstborn to attain low and a higher propensity to attain high education outcomes. Among the categorical interaction terms, a few coefficients are precisely estimated and the vector of interactions is jointly significant for the years of education outcome in the rightmost column only. In their majority, the coefficients of the interaction terms indicate that a high age at migration is worse for the firstborn than for their later born siblings. Therefore, we find no confirmation of the hypothesis that parents benefitted their oldest children by picking a particularly suitable age at migration. In effect, the negative effect of migrating at an older age is even larger for the firstborns, such that intentional advantages are not visible. While we cannot exclude that parents prevented worse outcomes for their firstborns we find no support for the hypothesis that firstborns benefitted from their parents' special attention.

Finally, we investigate whether our results are robust to controlling for a full set of birth order indicators. This is confirmed by the results in Appendix Table A.8: while we observe substantial differences in education outcomes by parity the main age at migration results are robust to these controls. Also, the birth order coefficients are mostly not jointly significant.

In our third set of tests, we investigate whether secular drifts in education outcomes affect our results: younger siblings might have benefited from educational expansions in quantitative and qualitative terms compared to their older siblings. This may generate an upward bias in the age at migration effect. As a first test we re-estimate our least squares models in Table 2 after replacing 'year of immigration' by 'year of birth' as a control variable; because we consider only 21 year olds a model controlling for both variables would be collinear. We find that independent of how we specify the year of birth indicator (e.g., categories or linear trend) there is a secular trend to higher educational attainment in our data. This trend may either 
reflect the overall education expansion or show that the educational system learned to address immigrants over time such that the outcomes of those arriving in later years are better than those of immigrants arriving a few years earlier.

To test whether a secular trend generates an upward bias in the causal age at migration effect we need to reestimate our fixed effects models accounting for both year of immigration and year of birth. Since we cannot identify both effects in a sample of 21 year old first generation immigrants, we add native and second generation immigrant siblings to our sample. If secular trends affect natives and immigrants similarly this allows us to estimate both, the effect of an education expansion over time as well as the standard model (e.g., Table 5). Table 9 shows the results. The coefficient for year of birth is highly significant and suggestive of education expansion over time which may comprise enhanced opportunities for educational advancement or an improvement in learning conditions for immigrants. However, our main age at migration effects are robust to this control; we obtain significant coefficient estimates which confirm prior results. Therefore, we are confident that our result of a negative age at migration effect is not determined by a secular trend.

In our fourth and final set of robustness tests, we evaluate alterations in data definitions. First, we omit observations of youths who indicate educational experience from abroad. Table A.9 presents the estimation results without these observations, which reduces the sample size to 290 observations. The key results are robust and not surprisingly the age at migration effects increase in magnitude. Second, we modify the matching of siblings by conditioning on having the same mother instead of living in the same household and migrating at the same time. Table A.10 shows the estimation results; the sample size slightly declines to 324 observations. Again, our key findings are robust. Third, we change our estimation sample by adding observations with missing values on education outcomes at age 21 . After substituting subsequently reported education outcomes, we can add ten observations to the sample and reestimate the models of 
Table 3. The results in Table A.11 confirm prior findings. Fourth and finally, we add those observations to the sample, which were dropped because they had indicated an "other" degree from the home country. The results in Table A.12 show that our findings are robust to this modification.

\section{Discussion and Conclusions}

We study the causal effect of age at migration for the educational attainment of first generation immigrants to Germany. We consider four separate education outcomes: not attaining a secondary school degree, attaining no more than a lower secondary school degree, attaining an upper secondary school degree, and completed years of education. All outcomes are measured at the age of 21. Descriptive results and linear regressions based on a sample of immigrant children with siblings confirm that it is beneficial to migrate early in life. Once we control for sibling fixed effects, the evidence becomes much stronger: the marginal effect of a later age at migration appears to be downward biased as long as family fixed effects are not accounted for. Immigrating at age 15 vs. age 1 increases the risk of not graduating from secondary school by 47 percentage points and reduces the number of years of education by almost 2 . These effects are in line with those found previously for Sweden and Norway.

In addition to large age at migration effects, we find strong evidence in favor of gender differences in the sensitivity of education outcomes to age at migration. We find the educational attainment of female immigrants to be much more sensitive to age at migration than the attainment of males. This, again, agrees with the prior literature and suggests that cultural differences between home and host country may be more important for female than male immigrant youth or that female immigrants take advantage of an early arrival in Germany whereas male immigrants do not.

The past literature paid much attention to the existence of a critical age of migration. Böhlmark (2008) as well as van den Berg et al. (2014) conclude that in Sweden the critical age 
at migration is at about 9. Based on our analyses we find that the critical age of migration for the German case is not higher than age 6 or $7 .{ }^{18}$ For the German educational system, this matches the typical age of school entry and suggests that those who enter the country after the typical age of school entry suffer significantly more in their educational attainment than those coming earlier. In fact, our baseline analysis suggests that entering the country at age 9 rather than at age 2 reduces the years of education completed by age 21 by 1.3 years and even more for girls than for boys. It appears plausible that the more homogeneous non-tracked school system in Sweden might generate immigrant adjustment patterns that differ from those in the more performance based German education system where elementary school grades can be decisive for secondary school track choice and long-run overall attainment.

We offer a number of robustness tests. Our results are robust to shifting the reference group to second generation immigrants instead of using the youngest first generation immigrants. We do not find that individual level unobservables are central to our results. We can account for time trends in educational attainment and show that the results hold up when the sample or key variables are redefined. One shortcoming of this research is that the results may not be generalizable to children who grow up without siblings because we cannot consider single children in our identification strategy.

Overall, we confirm the prior literature that there are strong causal effects of age at immigration on the educational attainment of first generation migrants. Our results suggest that the educational attainment of all immigrants and particularly of girls arriving in Germany after age 6 is attenuated due to their immigration experience. This is an important result and demands additional investments if the German educational system intends to offer late arriving adolescent immigrants the same educational opportunities than their earlier arriving peers.

18 We study immigrants with birth cohorts 1963-90 who immigrated between 1966 and 1996. As this is similar to Böhlmark's (2008) sample of immigrants with birth cohorts 1972-87 who immigrated to Sweden between 1972 and 2002 we do not believe that differences in sample drive the outcome heterogeneities. 


\section{Bibliography}

AB (Autorengruppe Bildungsberichterstattung), 2014a, Bildung in Deutschland 2014, Bertelsmann Verlag, Bielefeld.

AB (Autorengruppe Bildungsberichterstattung), 2014b, Tabellenanhang, http://www.bildungs bericht.de/index.html?seite=11135, last access: January 28, 2016.

Algan, Yann, Christian Dustmann, Albrecht Glitz, and Alan Manning, 2010, The economic situation of first- and second-generation immigrants in France, Germany, and the United Kingdom, Economic Journal 120 (542), F4-F30.

Åslund, Olof, Anders Böhlmark, and Oskar N. Skans, 2009, Age at migration and social integration, IZA Discussion Paper 4263, Institute for the Study of Labor (IZA), Bonn.

Åslund, Olof, Anders Böhlmark, and Oskar N. Skans, 2015, Childhood and family experiences and the social integration of young migrants, Labour Economics 35(1), 135-144.

BAMF (Bundesamt für Migration und Flüchtlinge), 2014, Migrationsbericht des Bundesamtes für Migration und Flüchtlinge im Auftrag der Bundesregierung. Migrationsbericht 2012, BAMF, Nürnberg.

Bauer, Thomas K., Sebastian Braun, and Michael Kvasnicka, 2013, The economic integration of forced migrants: Evidence for Post-War Germany, Economic Journal 123 (571), 9981024.

Beck, Audrey, Miles Corak, and Marta Tienda, 2012, Age at Immigration and the Adult Attainments of Child Migrants in the United States, Annals of the American Academy of Political and Social Science, 643, 134-159.

Bleakley, Hoyt and Aimee Chin, 2004, Language skills and earnings: Evidence from childhood immigrants, Review of Economics and Statistics 86(2), 481-496.

Bleakley, Hoyt and Aimee Chin, 2010, Age at arrival, English proficiency, and social assimilation among US immigrants, American Economic Journal: Applied Economics 2(1), 165-192.

BMI (Bundesinnenministerium), 2016, Pressemitteilungen, http://www.bmi.bund.de/Shared Docs/Pressemitteilungen/DE/2016/01/asylantraege-dezember-2015.html, last access: January 30, 2016.

Böhlmark, Anders, 2008, Age at immigration and school performance: A siblings analysis using Swedish register data, Labour Economics 15, 1366-1387.

Cahan, Sorel, Daniel Davis, and Rachel Staub, 2001, Age at Immigration and Scholastic Achievement in School-Age Children: Is There a Vulnerable Age?, International Migration Review 35(2), 587-595.

Cobb-Clark, Deborah, Mathias Sinning, and Steven Stillman, 2012, Migrant Youths' Educational Achievement: The Role of Institutions, Annals of the American Academy of Political and Social Science, 643, 18-45.

Colding, Bjørg, Leif Husted, and Hans Hummelgaard, 2009, Educational progression of second-generation immigrants and immigrant children, Economics of Education Review 28, 434-443.

Corak, Miles, 2012, Age at Immigration and the Education Outcomes of Children, in: Masten, Ann S. et al. (eds.), Realizing the Potential of Immigrant Youth, Cambridge University Press, Cambridge et al., 90-114. 
Cunha, Flavio and James J. Heckman, 2007, The Technology of Skill Formation, American Economic Review 97(2), 31-47.

Cunha, Flavio and James J. Heckman, 2009, The economics and psychology of inequality and human development, Journal of the European Economic Association 7(2-3), 320-364.

Felfe, Christina and Judith Saurer, 2014, Granting Birthright Citizenship - A Door Opener for Immigrant Children's Educational Participation and Success, cesifo Working Paper Series No. 4959, Munich.

Gjefsen, Hege Marie and Taryn Ann Galloway, Young immigrants: Age at migration and performance in education, discussion paper. Available from: http://www.svt.ntnu.no/iso/Marianne.Haraldsvik/Workshop2013/Papers2013/gjefseng alloway.pdf. Last accessed: January 27, 2016.

Guven, Cahit and Asadul Islam, 2015, Age at Migration, Language Proficiency and Socioeconomic Outcomes: Evidence from Australia, Demography 52,513-542.

Heineck, Guido and Regina T. Riphahn, 2009, Intergenerational Transmission of Educational Attainment in Germany - The Last Five Decades, Jahrbücher für Nationalökonomik und Statistik (Journal of Economics and Statistics) 229(1), 36-60.

KMK (Kultusministerkonferenz), 2014, The Education System in the Federal Republic of Germany 2012/2013, Secretariat of the Standing Conference of the Ministers of Education and Cultural Affairs of the Länder in the Federal Republic of Germany, Bonn. [from: http://www.kmk.org/fileadmin/doc/Dokumentation/Bildungswesen_en_pdfs/ dossier_en_ebook.pdf - last accessed Oct. 27, 2016].

OECD (Organisation for Economic Cooperation and Development), 2012, Education at a Glance 2012: OECD Indicators, OECD Publishing, Paris.

Schaafsma, Joseph and Arthur Sweetman, 2001, Immigrant earnings: age at immigration matters, Canadian Journal of Economics 34(4), 1066-1099.

SOEP (Socio-Economic Panel), 2014, data for years 1984-2013, version 30, SOEP, doi:10.5684/soep.v30.

Van den Berg, Gerard J., Petter Lundborg, Paul Nystedt and Dan-Olof Rooth, 2014, Critical periods during childhood and adolescence, Journal of the European Economic Association 12(6),1521-1557.

Van Ours, Jan C. and Justus Veenman, 2006, Age at immigration and educational attainment of young immigrants, Economics Letters 90(3), 310-316.

Wagner, Gert G., Joachim R. Frick, and Jürgen Schupp, 2007, The German Socio-Economic Panel Study (SOEP) - Scope, Evolution and Enhancements," Schmollers Jahrbuch (Journal of Applied Social Science Studies), 127, 139-69. 
Figure 1.1 No Secondary School Degree (Males Left, Females Right Panel)
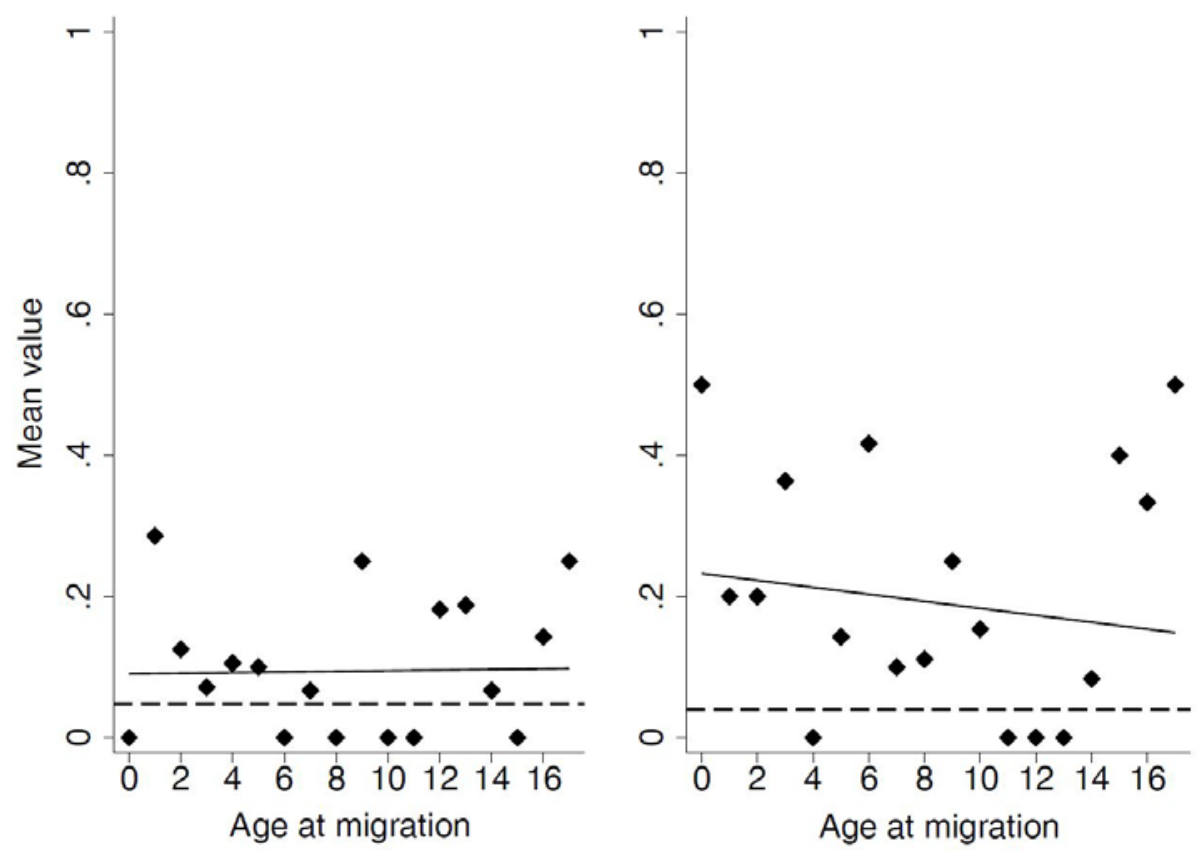

Figure 1.2 Up to Lower Secondary Degree (Males Left, Females Right Panel)
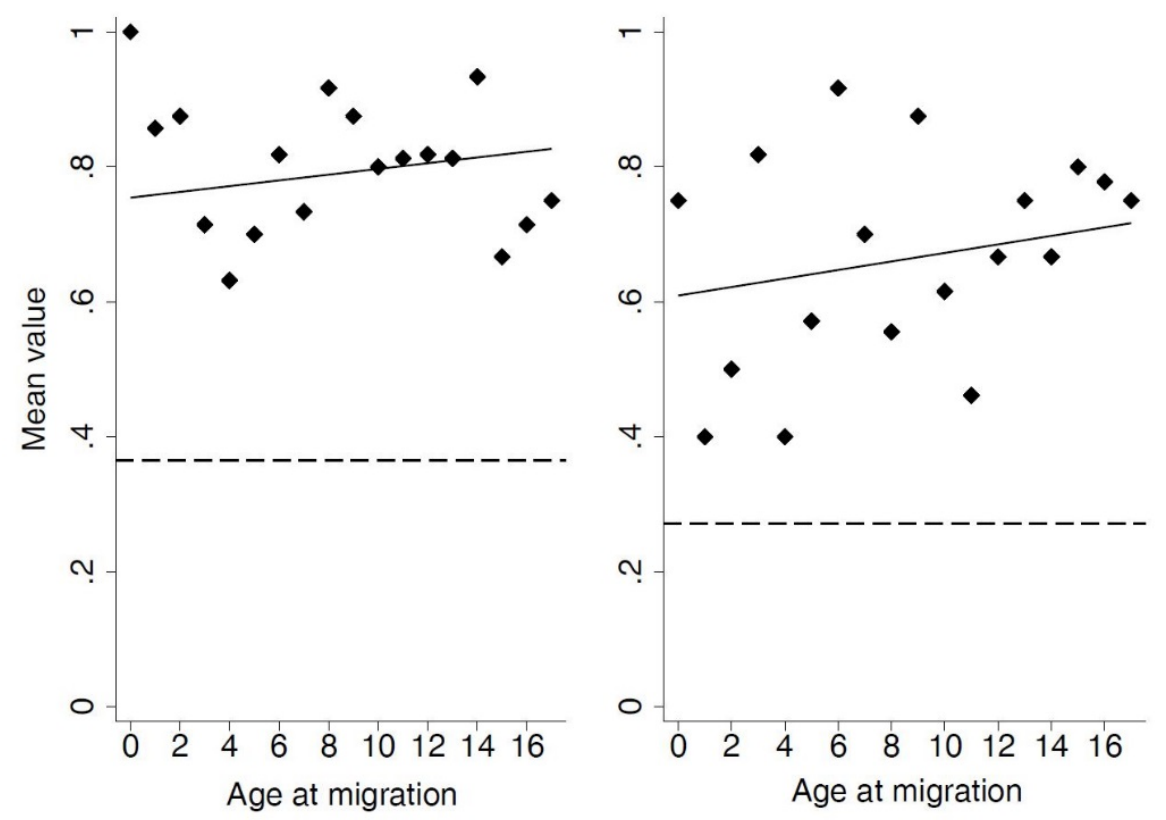


\section{Figure 1.3 Upper Secondary School Degree (Males Left, Females Right Panel)}
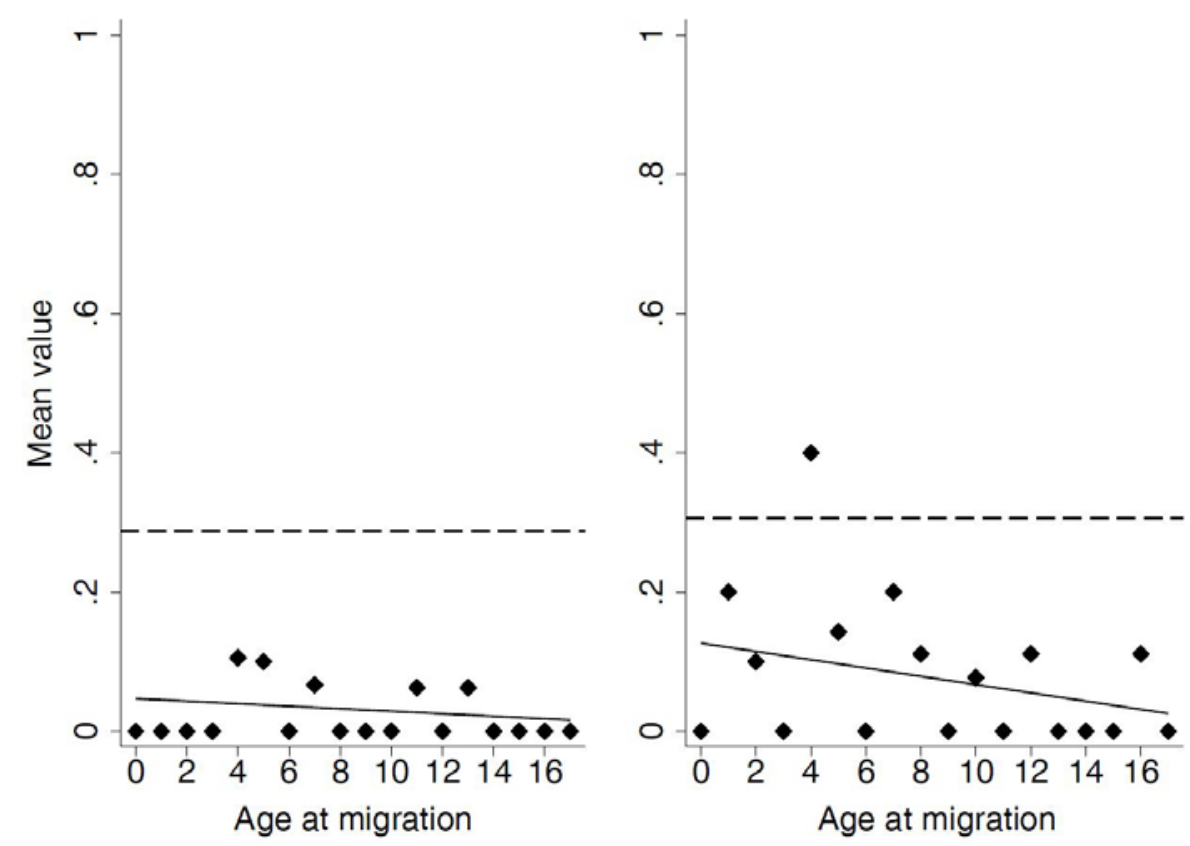

Figure 1.4 Years of Education (Males Left, Females Right Panel)
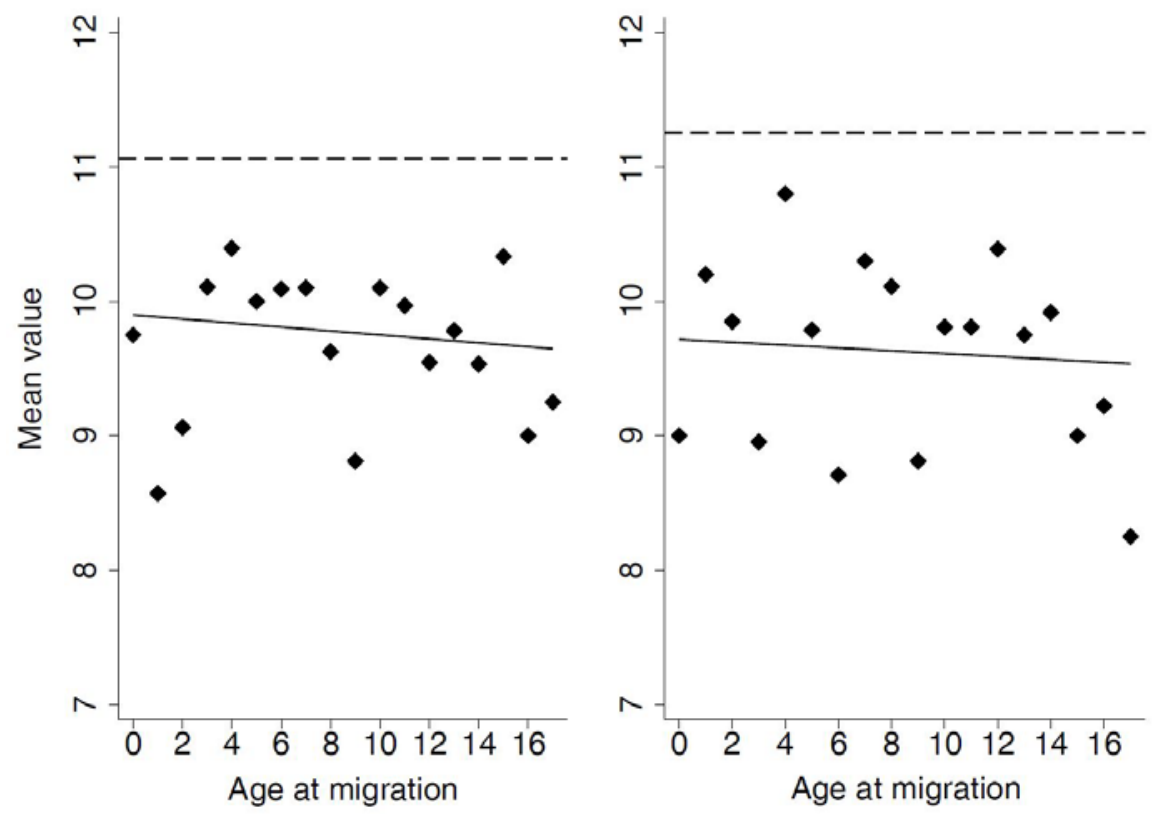

Note: Dots: mean values by age at migration; dashed line: mean value for natives observed at the age of 21; solid line: fitted values for immigrants.

Source: SOEP (1984-2013), own calculations. 
Figure 2 Marginal Effect of Migrating at a Given Age or Later - Full Sample

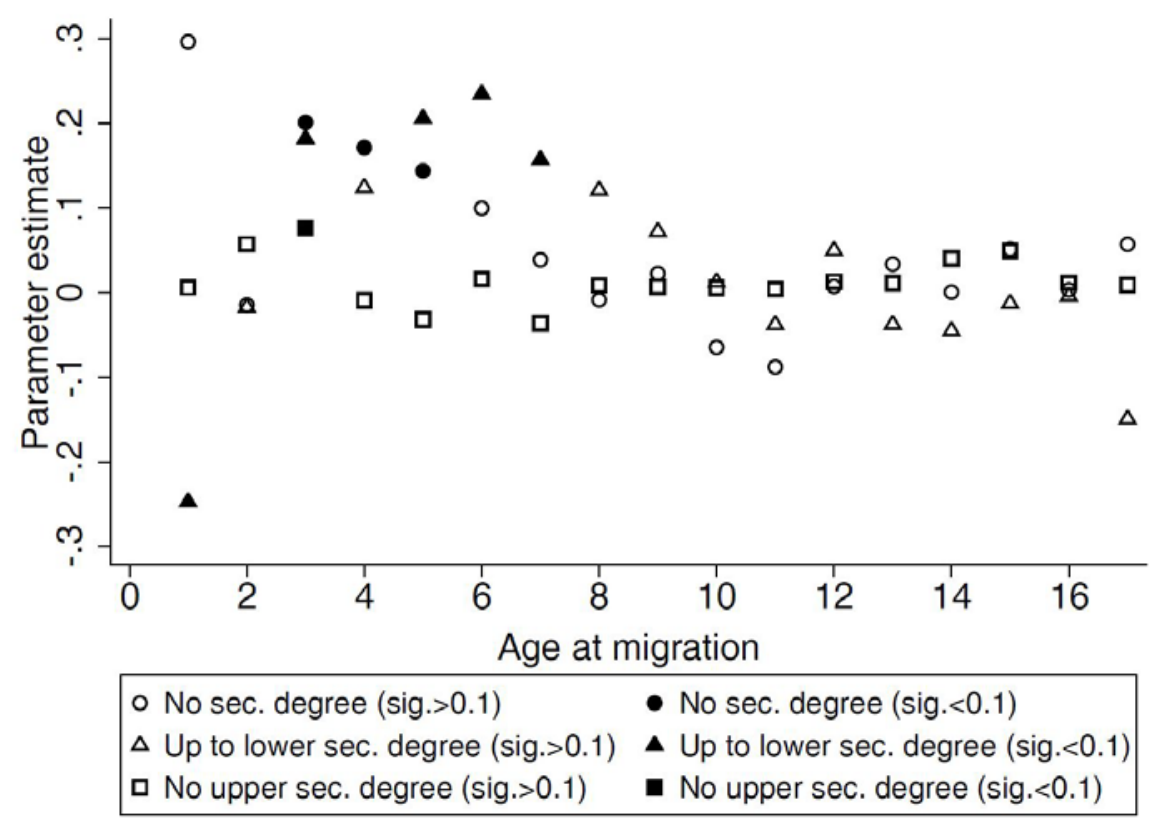

Note: The figure shows coefficient estimates, each generated in a separate regression on three different outcomes (no secondary degree, up to lower secondary degree and no upper secondary degree). The coefficients describe the causal effect of migrating at the given age or later. Empty symbols represent insignificant coefficient estimates, filled symbols represent coefficient estimates that are significant at the 10 percent level.

Source: SOEP (1984-2013), own calculations. 


\section{Figure 3.1 Marginal Effect of Migrating at a Given Age or Later - Males}

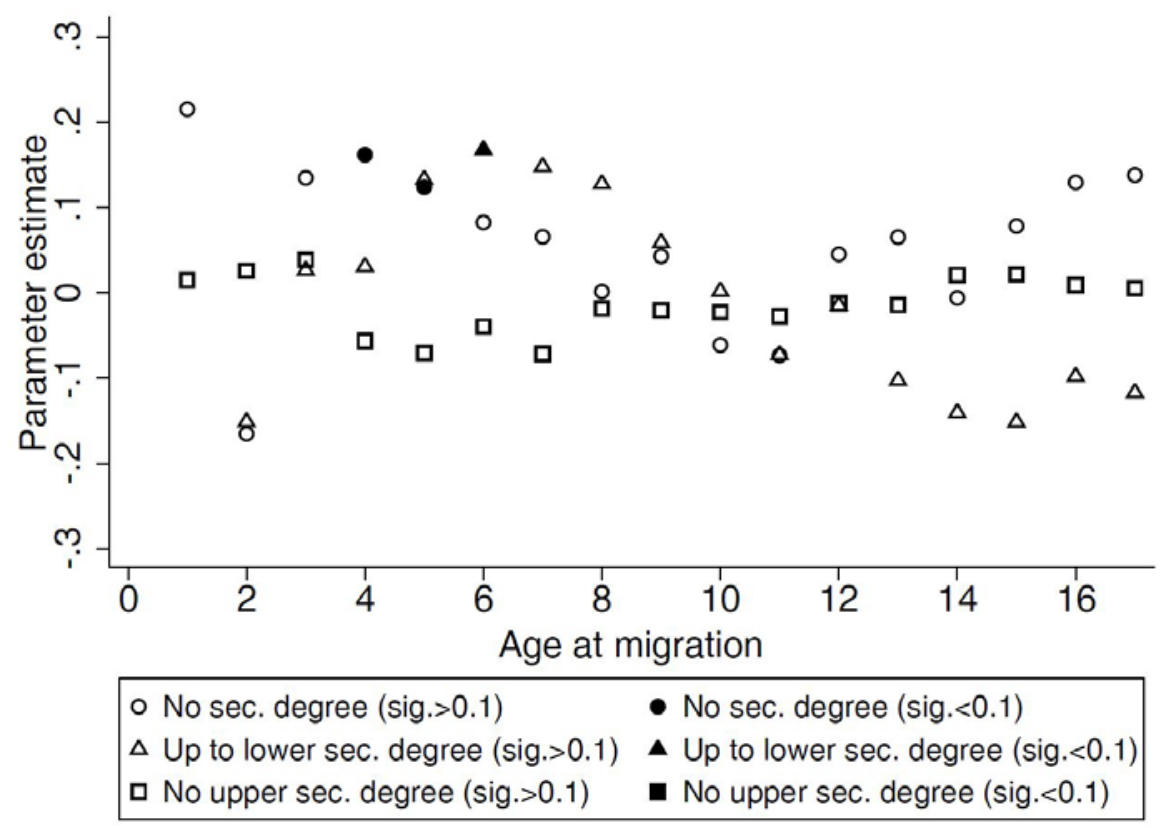

Figure 3.2 Marginal Effect of Migrating at a Given Age or Later - Females

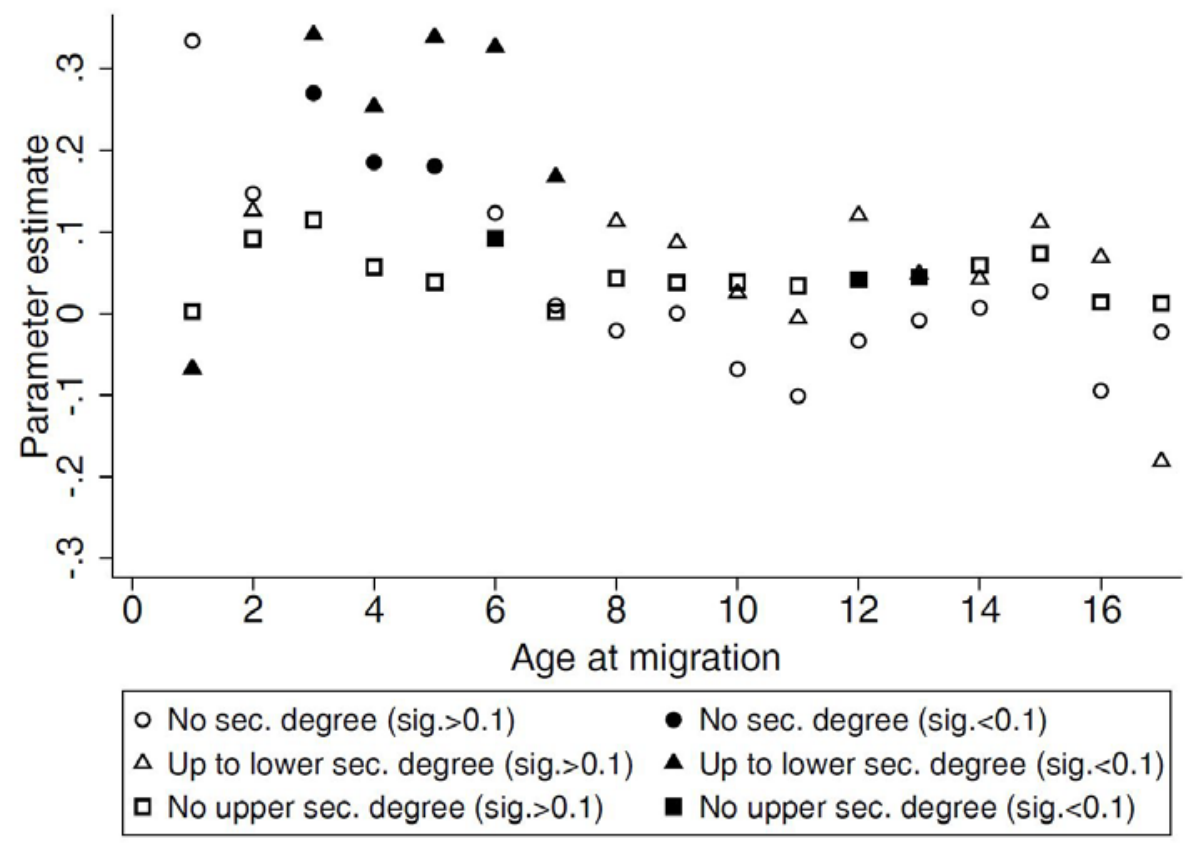

Note: See Figure 2. A large negative coefficient for 'up to lower secondary degree' at age 0 is not presented to avoid a cluttered depiction.

Source: SOEP (1984-2013), own calculations. 
Figure 4.1: Health Satisfaction (10 high, 0 low) by Age at Migration

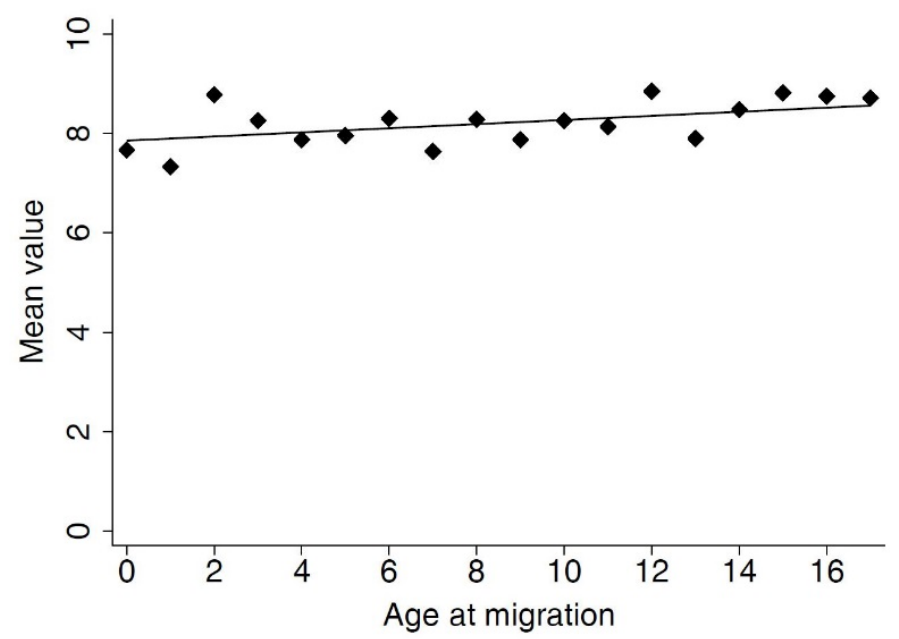

Figure 4.2: $\quad$ Language ability (5 high, 1 low) by Age at Migration

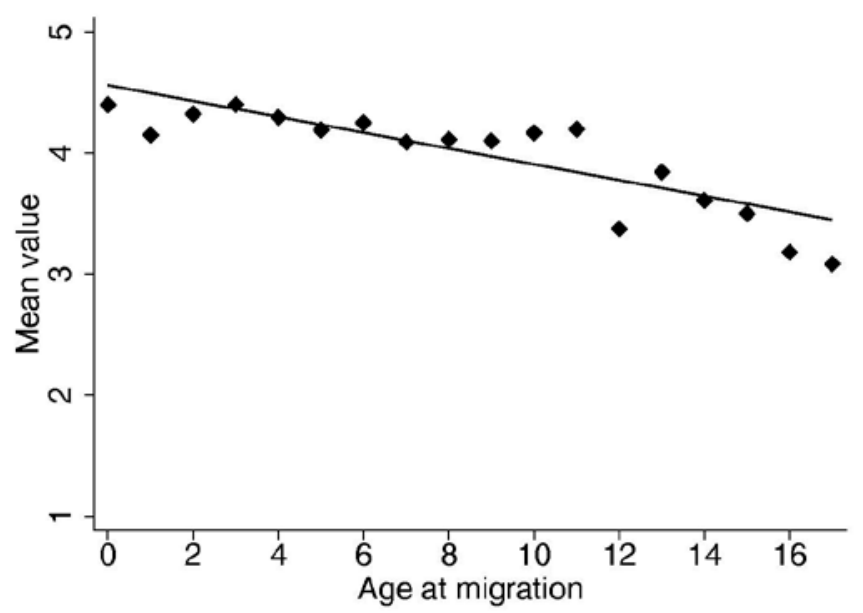

Figure 4.3: Life Satisfaction (10 high, 0 low) by Age at Migration

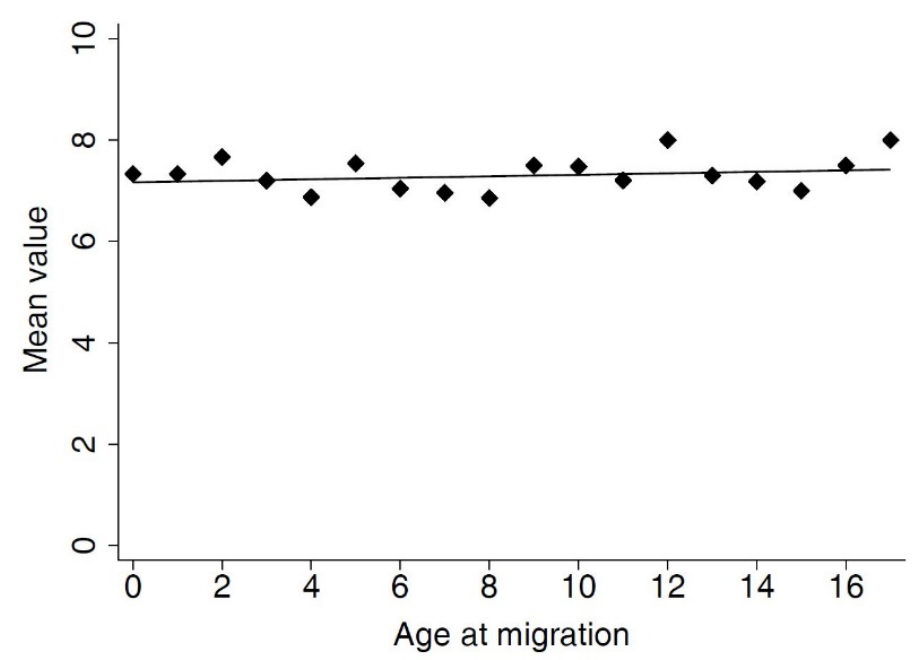


Figure 4.4: Contact to natives ( 0 no, 1 yes) by Age at Migration

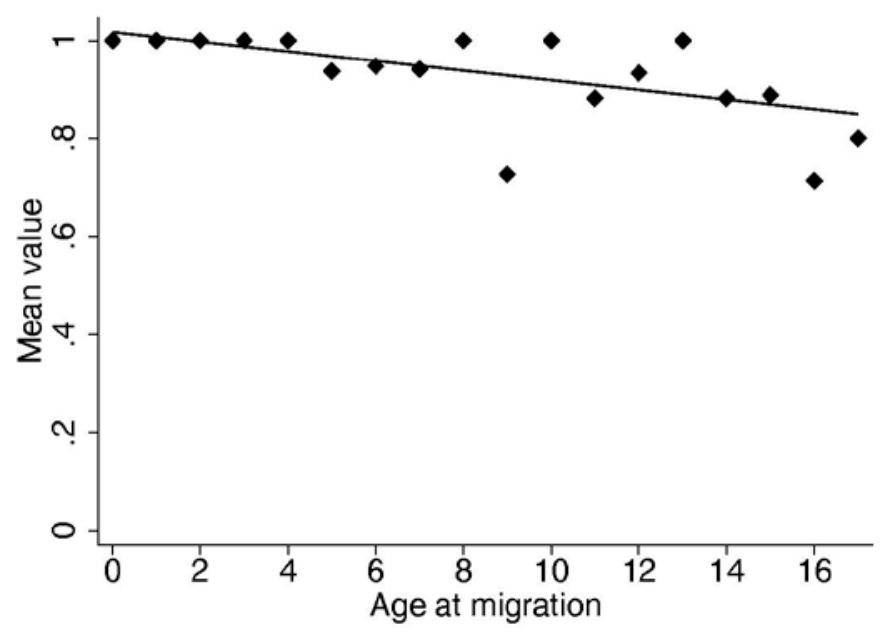

Figure 4.5: Intention to stay ( 0 no, 1 yes) by Age at Migration

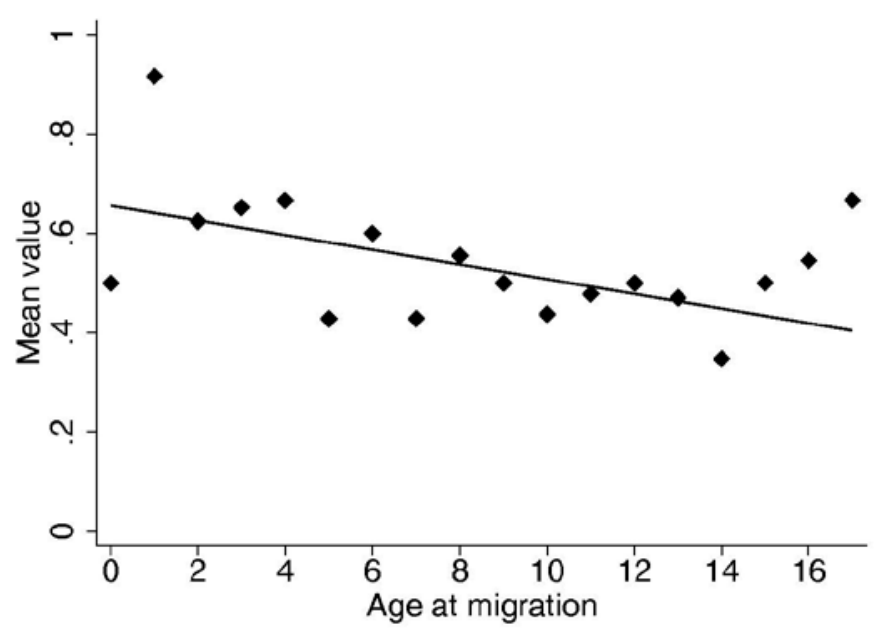

Note: Dots: mean values by age at migration observed at age 21; solid line: fitted values. Source: SOEP (1984-2013), own calculations. 
Table 1 Descriptive Statistics of Dependent Variables

\begin{tabular}{|c|c|c|c|c|c|c|c|c|c|}
\hline & & $\begin{array}{l}\text { o sec. } \\
\text { egree }\end{array}$ & Up to & $\begin{array}{l}\text { lower sec. } \\
\text { egree }\end{array}$ & & $\begin{array}{l}\text { per sec. } \\
\text { egree }\end{array}$ & & $\begin{array}{l}\text { ars of } \\
\text { cation }\end{array}$ & \\
\hline & Mean & Std. Dev. & Mean & Std. Dev. & Mean & Std. Dev. & Mean & Std. Dev. & $\mathrm{N}$ \\
\hline Total & 0.138 & 0.345 & 0.733 & 0.443 & 0.052 & 0.222 & 9.707 & 1.496 & 348 \\
\hline Male & 0.094 & 0.293 & 0.791 & 0.408 & 0.031 & 0.175 & 9.772 & 1.349 & 191 \\
\hline Female & 0.191 & 0.394 & 0.662 & 0.474 & 0.076 & 0.267 & 9.627 & 1.659 & 157 \\
\hline Age mig. $0-2$ & 0.222 & 0.422 & 0.694 & 0.467 & 0.056 & 0.232 & 9.375 & 1.592 & 36 \\
\hline Age mig. 3-5 & 0.137 & 0.346 & 0.658 & 0.478 & 0.096 & 0.296 & 9.979 & 1.735 & 73 \\
\hline Age mig. 6-8 & 0.116 & 0.323 & 0.783 & 0.415 & 0.058 & 0.235 & 9.804 & 1.491 & 69 \\
\hline Age mig. 9-11 & 0.088 & 0.286 & 0.721 & 0.452 & 0.029 & 0.170 & 9.654 & 1.276 & 68 \\
\hline Age mig. $12-14$ & 0.104 & 0.308 & 0.791 & 0.410 & 0.030 & 0.171 & 9.791 & 1.318 & 67 \\
\hline Age mig. $15-17$ & 0.257 & 0.443 & 0.743 & 0.443 & 0.029 & 0.169 & 9.229 & 1.516 & 35 \\
\hline Western Europe & 0.095 & 0.297 & 0.786 & 0.415 & 0.095 & 0.297 & 9.869 & 1.619 & 42 \\
\hline Eastern Europe & 0.078 & 0.269 & 0.583 & 0.496 & 0.097 & 0.298 & 10.150 & 1.526 & 103 \\
\hline Turkey & 0.203 & 0.404 & 0.872 & 0.335 & 0.006 & 0.076 & 9.288 & 1.354 & 172 \\
\hline Non-Europe & 0.032 & 0.180 & 0.387 & 0.495 & 0.097 & 0.301 & 10.339 & 1.350 & 31 \\
\hline
\end{tabular}

Note: Mean and SD give the mean of the dependent variable, AAM stands for mean age at migration and $\mathrm{N}$ is the number of observations.

Source: SOEP (1984-2013), own calculations. 


\begin{tabular}{lcccc}
\hline & $\begin{array}{c}\text { No sec. } \\
\text { degree }\end{array}$ & $\begin{array}{c}\text { Up to lower } \\
\text { sec. degree }\end{array}$ & $\begin{array}{c}\text { Upper sec. } \\
\text { degree }\end{array}$ & $\begin{array}{c}\text { Years of } \\
\text { education }\end{array}$ \\
\hline Panel A: Linear age at migration indicator & & & \\
Age mig./10 & 0.018 & $0.138 * *$ & -0.026 & -0.348 \\
& $(0.055)$ & $(0.061)$ & $(0.032)$ & $(0.660)$ \\
\hline
\end{tabular}

Panel B: Quadratic age at migration indicator

\begin{tabular}{lcccc} 
& $-0.407 * *$ & 0.204 & 0.017 & 1.037 \\
Age mig./10 & $(0.181)$ & $(0.185)$ & $(0.086)$ & $(0.660)$ \\
Age mig. ${ }^{2} / 100$ & $0.252 * *$ & -0.039 & -0.026 & $-0.822 * *$ \\
& $(0.102)$ & $(0.103)$ & $(0.051)$ & $(0.363)$ \\
\hline F-Test p-value & $0.044^{* *}$ & $0.075^{*}$ & 0.673 & $0.021^{* *}$ \\
\hline Panel C: Categorical age at migration indicators & & \\
Age mig. 3-5 & -0.069 & -0.007 & 0.016 & $0.507 *$ \\
& $(0.076)$ & $(0.089)$ & $(0.044)$ & $(0.307)$ \\
Age mig. 6-8 & -0.064 & 0.131 & 0.000 & $0.264 * * *$ \\
& $(0.079)$ & $(0.084)$ & $(0.041)$ & $(0.313)$ \\
Age mig. 9-11 & -0.074 & $0.164 *$ & -0.044 & -0.065 \\
& $(0.083)$ & $(0.088)$ & $(0.041)$ & $(0.315)$ \\
Age mig. 12-14 & -0.051 & 0.153 & -0.016 & 0.198 \\
& $(0.086)$ & $(0.094)$ & $(0.042)$ & $(0.339)$ \\
Age mig. 15-17 & 0.110 & $0.201 *$ & -0.040 & -0.568 \\
& $(0.103)$ & $(0.113)$ & $(0.051)$ & $(0.383)$ \\
\hline F-Test p-value & 0.258 & $0.075 *$ & 0.679 & $0.019 * *$ \\
\hline
\end{tabular}

Note: Dependent variables as specified. Robust standard errors are shown in parentheses. Additional explanatory variables: female, firstborn, region of origin, parental education, year of immigration, federal state, and a constant. The sample is identical to that used in fixed effects analyses. Number of observations: 348. Significance level: $*<0.1, * *<0.05, * * *<0.01$.

Source: SOEP (1984-2013), own calculations. 
Table 3 Fixed Effects Estimation Results

\begin{tabular}{lcccc}
\hline & $\begin{array}{c}\text { No sec. } \\
\text { degree }\end{array}$ & $\begin{array}{c}\text { Up to lower } \\
\text { sec. degree }\end{array}$ & $\begin{array}{c}\text { Upper sec. } \\
\text { degree }\end{array}$ & $\begin{array}{c}\text { Years of } \\
\text { education }\end{array}$ \\
\hline Panel A: Linear age at migration indicator & & & \\
Age mig./10 & 0.175 & $0.267 *$ & -0.048 & -0.684 \\
& $(0.114)$ & $(0.153)$ & $(0.038)$ & $(0.478)$ \\
\hline
\end{tabular}

Panel B: Quadratic age at migration indicators

\begin{tabular}{lcccc} 
& $0.436 *$ & $0.614 * *$ & -0.022 & -1.400 \\
Age mig./10 & $(0.235)$ & $(0.250)$ & $(0.090)$ & $(1.008)$ \\
Age mig. ${ }^{2} / 100$ & -0.152 & -0.202 & -0.015 & 0.416 \\
& $(0.110)$ & $(0.130)$ & $(0.042)$ & $(0.482)$ \\
\hline F-Test p-value & 0.163 & $0.042 * *$ & 0.369 & 0.286 \\
\hline \multicolumn{5}{c}{ Panel C: Categorical age at migration indicators } \\
Age mig. 3-5 & $0.207 * * *$ & $0.164 * *$ & $-0.087 *$ & $-0.596 *$ \\
& $(0.076)$ & $(0.082)$ & $(0.047)$ & $(0.345)$ \\
Age mig. 6-8 & $0.300 * * *$ & $0.397 * * *$ & -0.105 & $-1.065 * *$ \\
& $(0.103)$ & $(0.122)$ & $(0.064)$ & $(0.485)$ \\
Age mig. 9-11 & $0.336 * * *$ & $0.443 * * *$ & $-0.123 *$ & $-1.345 * *$ \\
& $(0.118)$ & $(0.143)$ & $(0.068)$ & $(0.525)$ \\
Age mig. 12-14 & $0.359 * *$ & $0.525 * * *$ & $-0.136 *$ & $-1.132 *$ \\
& $(0.143)$ & $(0.164)$ & $(0.072)$ & $(0.600)$ \\
Age mig. 15-17 & $0.471^{* * *}$ & $0.601 * * *$ & $-0.204 * *$ & $-1.938 * *$ \\
& $(0.174)$ & $(0.224)$ & $(0.088)$ & $(0.747)$ \\
\hline F-Test p-value & $0.074 *$ & $0.033^{* *}$ & 0.280 & $0.065 *$ \\
\hline
\end{tabular}

Note: Dependent variables as specified. Robust standard errors are in parentheses. Additional explanatory variables: female, firstborn, year of immigration, and a constant. Number of observations: 348. Significance level: $*<0.1, * *<0.05, * * *<0.01$.

Source: SOEP (1984-2013), own calculations. 
Table 4 Fixed Effects Estimation Results by Gender

\begin{tabular}{|c|c|c|c|c|}
\hline & $\begin{array}{c}\text { No sec. } \\
\text { degree }\end{array}$ & $\begin{array}{l}\text { Up to lower } \\
\text { sec. degree }\end{array}$ & $\begin{array}{c}\text { Upper sec. } \\
\text { degree }\end{array}$ & $\begin{array}{c}\text { Years of } \\
\text { education }\end{array}$ \\
\hline \multicolumn{5}{|c|}{ Panel A: Linear age at migration indicator } \\
\hline Age mig./10*fem & $\begin{array}{r}0.162 \\
(0.125)\end{array}$ & $\begin{array}{c}0.321 * \\
(0.167)\end{array}$ & $\begin{array}{l}-0.085 * \\
(0.049)\end{array}$ & $\begin{array}{l}-0.942 * \\
(0.504)\end{array}$ \\
\hline Age mig./10*male & $\begin{array}{r}0.191 \\
(0.125)\end{array}$ & $\begin{array}{r}0.201 \\
(0.156)\end{array}$ & $\begin{array}{r}-0.001 \\
(0.041)\end{array}$ & $\begin{array}{r}-0.366 \\
(0.523)\end{array}$ \\
\hline Female & $\begin{array}{r}0.107 \\
(0.102) \\
\end{array}$ & $\begin{array}{l}-0.235 * * \\
(0.108) \\
\end{array}$ & $\begin{array}{r}0.081 \\
(0.051) \\
\end{array}$ & $\begin{array}{r}0.373 \\
(0.373) \\
\end{array}$ \\
\hline \multicolumn{5}{|c|}{ Panel B: Quadratic age at migration indicators } \\
\hline Age mig./10*fem & $\begin{array}{c}0.614 * \\
(0.313)\end{array}$ & $\begin{array}{l}0.732 * * \\
(0.332)\end{array}$ & $\begin{array}{r}-0.160 \\
(0.139)\end{array}$ & $\begin{array}{l}-2.371 * \\
(1.351)\end{array}$ \\
\hline Age mig./10*male & $\begin{array}{r}0.236 \\
(0.271)\end{array}$ & $\begin{array}{r}0.551 \\
(0.361)\end{array}$ & $\begin{array}{r}0.088 \\
(0.099)\end{array}$ & $\begin{array}{c}-0.637 \\
(1.106)\end{array}$ \\
\hline Age mig. ${ }^{2} / 100 *$ fem & $\begin{array}{l}-0.258 * \\
(0.153)\end{array}$ & $\begin{array}{r}-0.234 \\
(0.175)\end{array}$ & $\begin{array}{r}0.043 \\
(0.067)\end{array}$ & $\begin{array}{r}0.814 \\
(0.665)\end{array}$ \\
\hline Age mig. ${ }^{2} / 100 *$ male & $\begin{array}{r}-0.028 \\
(0.150)\end{array}$ & $\begin{array}{r}-0.209 \\
(0.191)\end{array}$ & $\begin{array}{c}-0.053 \\
(0.047)\end{array}$ & $\begin{array}{r}0.164 \\
(0.584)\end{array}$ \\
\hline Female & $\begin{array}{r}-0.029 \\
(0.137) \\
\end{array}$ & $\begin{array}{r}-0.273 \\
(0.181) \\
\end{array}$ & $\begin{array}{c}0.131 * \\
(0.076) \\
\end{array}$ & $\begin{array}{r}0.768 \\
(0.545) \\
\end{array}$ \\
\hline $\begin{array}{l}F \text { test } p \text {-value }- \text { fem. } \\
F \text { test } p \text {-value }- \text { males }\end{array}$ & $\begin{array}{l}0.143 \\
0.316\end{array}$ & $\begin{array}{l}0.053 * \\
0.498\end{array}$ & $\begin{array}{l}0.219 \\
0.513\end{array}$ & $\begin{array}{l}0.119 \\
0.759\end{array}$ \\
\hline \multicolumn{5}{|c|}{ Panel C: Categorical age at migration indicators } \\
\hline Age mig. $3-5 *$ fem & $\begin{array}{l}0.291 \text { ** } \\
(0.116)\end{array}$ & $\begin{array}{l}0.305 \text { ** } \\
(0.121)\end{array}$ & $\begin{array}{r}-0.056 \\
(0.060)\end{array}$ & $\begin{array}{l}-1.239 * * \\
(0.500)\end{array}$ \\
\hline Age mig. $6-8 *$ fem & $\begin{array}{l}0.432 \text { *** } \\
(0.163)\end{array}$ & $\begin{array}{l}0.636 * * * \\
(0.150)\end{array}$ & $\begin{array}{l}-0.185 * \\
(0.105)\end{array}$ & $\begin{array}{l}-1.807 * * * \\
(0.691)\end{array}$ \\
\hline Age mig. $9-11 *$ fem & $\begin{array}{l}0.401 \text { *** } \\
(0.136)\end{array}$ & $\begin{array}{l}0.509 * * * \\
(0.180)\end{array}$ & $\begin{array}{l}-0.147 * \\
(0.081)\end{array}$ & $\begin{array}{l}-1.870 * * * \\
(0.604)\end{array}$ \\
\hline Age mig. $12-14 *$ fem & $\begin{array}{l}0.381 \text { ** } \\
(0.177)\end{array}$ & $\begin{array}{l}0.677 * * * \\
(0.190)\end{array}$ & $\begin{array}{l}-0.173 * \\
(0.089)\end{array}$ & $\begin{array}{l}-1.647 * * \\
(0.695)\end{array}$ \\
\hline Age mig. $15-17 *$ fem & $\begin{array}{l}0.522 \text { ** } \\
(0.209)\end{array}$ & $\begin{array}{l}0.834 * * * \\
(0.241)\end{array}$ & $\begin{array}{l}-0.238 * * \\
(0.104)\end{array}$ & $\begin{array}{l}-2.721 * * * \\
(0.808)\end{array}$ \\
\hline Age mig. $3-5 *$ male & $\begin{array}{r}0.126 \\
(0.118)\end{array}$ & $\begin{array}{r}0.025 \\
(0.114)\end{array}$ & $\begin{array}{l}-0.103 * \\
(0.056)\end{array}$ & $\begin{array}{r}0.053 \\
(0.423)\end{array}$ \\
\hline Age mig. $6-8 *$ male & $\begin{array}{r}0.188 \\
(0.118)\end{array}$ & $\begin{array}{r}0.184 \\
(0.137)\end{array}$ & $\begin{array}{r}-0.041 \\
(0.039)\end{array}$ & $\begin{array}{r}-0.333 \\
(0.486)\end{array}$ \\
\hline Age mig. 9-11*male & $\begin{array}{c}0.264 * \\
(0.143)\end{array}$ & $\begin{array}{l}0.354 \text { ** } \\
(0.154)\end{array}$ & $\begin{array}{r}-0.081 \\
(0.060)\end{array}$ & $\begin{array}{r}-0.718 \\
(0.559)\end{array}$ \\
\hline Age mig. $12-14 *$ male & $\begin{array}{l}0.338 * * \\
(0.156)\end{array}$ & $\begin{array}{l}0.375 * * \\
(0.178)\end{array}$ & $\begin{array}{c}-0.092 \\
(0.059)\end{array}$ & $\begin{array}{r}-0.552 \\
(0.597)\end{array}$ \\
\hline Age mig. $15-17 *$ male & $\begin{array}{l}0.457 * * \\
(0.195)\end{array}$ & $\begin{array}{r}0.344 \\
(0.250)\end{array}$ & $\begin{array}{l}-0.143 * * \\
(0.070)\end{array}$ & $\begin{array}{r}-1.060 \\
(0.800)\end{array}$ \\
\hline Female & $\begin{array}{r}-0.045 \\
(0.130) \\
\end{array}$ & $\begin{array}{l}-0.427 * * * \\
(0.143)\end{array}$ & $\begin{array}{r}0.068 \\
(0.058) \\
\end{array}$ & $\begin{array}{l}1.083 * * \\
(0.463)\end{array}$ \\
\hline F test p-value - fem. & $0.042 * *$ & $0.002 * * *$ & 0.310 & $0.018 * *$ \\
\hline F test p-value - males & 0.313 & 0.116 & 0.286 & 0.613 \\
\hline
\end{tabular}

Note: Dependent variables as specified. Additional explanatory variables: firstborn, year of immigration, and a constant. Number of male observations: 191, number of female observations: 157. The F-tests test the joint significance of the gender specific age at migration interaction terms.

Significance level: $*<0.1, * *<0.05, * * *<0.01$.

Source: SOEP (1984-2013), own calculations. 
Table 5 Fixed Effects Estimation Results - Controlling for Language Ability

\begin{tabular}{|c|c|c|c|c|}
\hline & $\begin{array}{c}\text { No sec. } \\
\text { degree }\end{array}$ & $\begin{array}{l}\text { Up to lower } \\
\text { sec. degree }\end{array}$ & $\begin{array}{c}\text { Upper sec. } \\
\text { degree }\end{array}$ & $\begin{array}{r}\begin{array}{c}\text { Years of } \\
\text { education }\end{array} \\
\end{array}$ \\
\hline \multicolumn{5}{|c|}{ Panel A: Linear age at migration indicator } \\
\hline Age mig./10 & $\begin{array}{r}0.210 \\
(0.145)\end{array}$ & $\begin{array}{r}0.084 \\
(0.152)\end{array}$ & $\begin{array}{r}-0.044 \\
(0.036)\end{array}$ & $\begin{array}{r}-0.724 \\
(0.549)\end{array}$ \\
\hline Language ability - very low & $\begin{array}{l}0.349 * * \\
(0.143)\end{array}$ & $\begin{array}{l}0.238 * * * \\
(0.085)\end{array}$ & $\begin{array}{l}-0.026 \\
(0.019)\end{array}$ & $\begin{array}{l}-1.112 * * \\
(0.530)\end{array}$ \\
\hline Language ability - low & $\begin{array}{r}0.118 \\
(0.093)\end{array}$ & $\begin{array}{l}0.228 * * \\
(0.094)\end{array}$ & $\begin{array}{l}-0.048 \\
(0.037)\end{array}$ & $\begin{array}{l}-0.756 * \\
(0.410)\end{array}$ \\
\hline Language ability - medium & $\begin{array}{r}0.045 \\
(0.057)\end{array}$ & $\begin{array}{l}0.252 * * * \\
(0.070)\end{array}$ & $\begin{array}{l}-0.021 \\
(0.014)\end{array}$ & $\begin{array}{l}-0.396 \\
(0.244)\end{array}$ \\
\hline F test p-value - language & 0.102 & $0.005 * * *$ & 0.530 & 0.140 \\
\hline \multicolumn{5}{|c|}{ Panel B: Quadratic age at migration indicators } \\
\hline Age mig./10 & $\begin{array}{l}0.574 * * \\
(0.281)\end{array}$ & $\begin{array}{l}0.532 * * \\
(0.259)\end{array}$ & $\begin{array}{l}-0.020 \\
(0.097)\end{array}$ & $\begin{array}{l}-2.011 * \\
(1.093)\end{array}$ \\
\hline Age mig. ${ }^{2} / 100$ & $\begin{array}{l}-0.212 \\
(0.130)\end{array}$ & $\begin{array}{l}-0.261 * \\
(0.140)\end{array}$ & $\begin{array}{l}-0.014 \\
(0.050)\end{array}$ & $\begin{array}{r}0.751 \\
(0.528)\end{array}$ \\
\hline Language ability - very low & $\begin{array}{l}0.359 * * \\
(0.152)\end{array}$ & $\begin{array}{l}0.251 * * * \\
(0.080)\end{array}$ & $\begin{array}{l}-0.025 \\
(0.020)\end{array}$ & $\begin{array}{l}-1.150 * * \\
(0.544)\end{array}$ \\
\hline Language ability - low & $\begin{array}{r}0.120 \\
(0.093)\end{array}$ & $\begin{array}{l}0.230 * * \\
(0.089)\end{array}$ & $\begin{array}{l}-0.048 \\
(0.037)\end{array}$ & $\begin{array}{r}-0.762 * \\
(0.408)\end{array}$ \\
\hline Language ability - medium & $\begin{array}{r}0.046 \\
(0.056)\end{array}$ & $\begin{array}{l}0.254 * * * \\
(0.068)\end{array}$ & $\begin{array}{l}-0.021 \\
(0.015)\end{array}$ & $\begin{array}{l}-0.400 * \\
(0.240)\end{array}$ \\
\hline $\begin{array}{l}\mathrm{F} \text { test } \mathrm{p} \text {-value - AAM } \\
\mathrm{F} \text { test } \mathrm{p} \text {-value - language } \\
\end{array}$ & $\begin{array}{l}0.124 \\
0.115 \\
\end{array}$ & $\begin{array}{l}0.120 \\
0.003 * * *\end{array}$ & $\begin{array}{l}0.435 \\
0.540 \\
\end{array}$ & $\begin{array}{l}0.175 \\
0.131 \\
\end{array}$ \\
\hline \multicolumn{5}{|c|}{ Panel C: Categorical age at migration indicators } \\
\hline Age mig. 3-5 & $\begin{array}{l}0.216 \text { *** } \\
(0.082)\end{array}$ & $\begin{array}{r}0.118 \\
(0.081)\end{array}$ & $\begin{array}{l}-0.084 * \\
(0.049)\end{array}$ & $\begin{array}{l}-0.643 * \\
(0.336)\end{array}$ \\
\hline Age mig. 6-8 & $\begin{array}{l}0.329 * * * \\
(0.114)\end{array}$ & $\begin{array}{l}0.291 * * \\
(0.119)\end{array}$ & $\begin{array}{l}-0.104 \\
(0.065)\end{array}$ & $\begin{array}{l}-1.075 * * \\
(0.476)\end{array}$ \\
\hline Age mig. 9-11 & $\begin{array}{l}0.408 \text { *** } \\
(0.142)\end{array}$ & $\begin{array}{l}0.314 * * \\
(0.146)\end{array}$ & $\begin{array}{l}-0.145 * \\
(0.074)\end{array}$ & $\begin{array}{l}-1.462 * * \\
(0.573)\end{array}$ \\
\hline Age mig. 12-14 & $\begin{array}{l}0.414^{* *} \\
(0.174)\end{array}$ & $\begin{array}{l}0.313 * \\
(0.166)\end{array}$ & $\begin{array}{l}-0.140 * \\
(0.079)\end{array}$ & $\begin{array}{l}-1.092 \\
(0.667)\end{array}$ \\
\hline Age mig. $15-17$ & $\begin{array}{l}0.525 * * \\
(0.222)\end{array}$ & $\begin{array}{r}0.338 \\
(0.222)\end{array}$ & $\begin{array}{l}-0.219 * * \\
(0.101)\end{array}$ & $\begin{array}{l}-1.849 * * \\
(0.859)\end{array}$ \\
\hline Language ability - very low & $\begin{array}{l}0.340 * * \\
(0.144)\end{array}$ & $\begin{array}{l}0.250 * * * \\
(0.081)\end{array}$ & $\begin{array}{l}-0.013 \\
(0.022)\end{array}$ & $\begin{array}{l}-1.098 * * \\
(0.498)\end{array}$ \\
\hline Language ability - low & $\begin{array}{r}0.099 \\
(0.088)\end{array}$ & $\begin{array}{l}0.207 * * \\
(0.089)\end{array}$ & $\begin{array}{l}-0.039 \\
(0.033)\end{array}$ & $\begin{array}{l}-0.714 * \\
(0.380)\end{array}$ \\
\hline Language ability - medium & $\begin{array}{r}0.028 \\
(0.054) \\
\end{array}$ & $\begin{array}{l}0.232 * * * \\
(0.069)\end{array}$ & $\begin{array}{l}-0.012 \\
(0.013) \\
\end{array}$ & $\begin{array}{l}-0.349 \\
(0.235) \\
\end{array}$ \\
\hline $\begin{array}{l}\text { F test } p \text {-value - AAM } \\
\text { F test } p \text {-value - language }\end{array}$ & $\begin{array}{l}0.080 * \\
0.123\end{array}$ & $\begin{array}{l}0.237 \\
0.006 * * *\end{array}$ & $\begin{array}{l}0.366 \\
0.632\end{array}$ & $\begin{array}{l}0.067 * \\
0.121\end{array}$ \\
\hline
\end{tabular}

Note: Dependent variables as specified. Robust standard errors are in parentheses. Language ability reference: high. Additional explanatory variables: female, firstborn, year of immigration, and a constant. Number of observations: 302. Significance level: $*<0.1, * *<0.05$, $* * *<0.01$.

Source: SOEP (1984-2013), own calculations. 
Table 6 Fixed Effects Estimation Results $-1^{\text {st }}$ and $2^{\text {nd }}$ Generation

\begin{tabular}{lcccc}
\hline & $\begin{array}{c}\text { No sec. } \\
\text { degree }\end{array}$ & $\begin{array}{c}\text { Up to lower } \\
\text { sec. degree }\end{array}$ & $\begin{array}{c}\text { Upper sec. } \\
\text { degree }\end{array}$ & $\begin{array}{c}\text { Years of } \\
\text { education }\end{array}$ \\
\hline Panel A: Linear age at migration indicator & & & \\
Age mig./10 & $0.195 * * *$ & $0.119 *$ & -0.035 & $-0.800 * * *$ \\
& $(0.070)$ & $(0.067)$ & $(0.033)$ & $(0.266)$ \\
2nd Generation & 0.047 & -0.036 & 0.029 & -0.124 \\
& $(0.065)$ & $(0.063)$ & $(0.039)$ & $(0.282)$ \\
\hline
\end{tabular}

Panel B: Quadratic age at migration indicators

\begin{tabular}{lcccc} 
Age mig./10 & 0.186 & $0.484 * *$ & -0.117 & $-1.664 * *$ \\
& $(0.185)$ & $(0.188)$ & $(0.096)$ & $(0.815)$ \\
Age mig. ${ }^{2} / 100$ & 0.005 & $-0.218 * *$ & 0.049 & 0.516 \\
& $(0.106)$ & $(0.105)$ & $(0.048)$ & $(0.434)$ \\
2nd Generation & 0.044 & 0.061 & 0.007 & -0.354 \\
& $(0.081)$ & $(0.075)$ & $(0.046)$ & $(0.362)$ \\
\hline F-Test p-value & $0.021 * *$ & $0.025 * *$ & 0.449 & $0.009 * * *$ \\
\hline
\end{tabular}

\section{Panel C: Categorical age at migration indicators}

\begin{tabular}{lcccc} 
Age mig. 0-2 & -0.052 & 0.003 & -0.010 & 0.224 \\
& $(0.069)$ & $(0.058)$ & $(0.044)$ & $(0.319)$ \\
Age mig. 3-5 & 0.063 & 0.054 & -0.035 & -0.270 \\
& $(0.062)$ & $(0.069)$ & $(0.041)$ & $(0.261)$ \\
Age mig. 6-8 & 0.097 & $0.219 * * *$ & $-0.110 * *$ & $-0.684 * *$ \\
& $(0.066)$ & $(0.069)$ & $(0.047)$ & $(0.278)$ \\
Age mig. 9-11 & $0.142 * *$ & $0.206 * * *$ & $-0.070 * *$ & $-0.811 * * *$ \\
& $(0.063)$ & $(0.072)$ & $(0.035)$ & $(0.262)$ \\
Age mig. 12-14 & $0.155^{* *}$ & $0.196 * * *$ & $-0.065 *$ & $-0.515 * *$ \\
& $(0.073)$ & $(0.073)$ & $(0.039)$ & $(0.261)$ \\
Age mig. 15-17 & $0.309 * * *$ & $0.194 * *$ & $-0.094 * *$ & $-1.245 * * *$ \\
& $(0.102)$ & $(0.088)$ & $(0.041)$ & $(0.333)$ \\
\hline F-Test p-value & $0.056 *$ & $0.022 * *$ & 0.231 & $0.002 * *$ \\
\hline
\end{tabular}

Note: Dependent variables as specified. Robust standard errors are in parentheses. Additional explanatory variables: female, firstborn, and a constant. In Panel C we do not control for a 2nd generation main effect because it constitutes the reference group. Number of observations: 1,006. Significance level: $*<0.1, * *<0.05, * * *<0.01$.

Source: SOEP (1984-2013), own calculations. 
Table 7 Fixed Effects Estimation Results - Siblings Migrating in same Calendar Year

\begin{tabular}{cccc}
\hline No sec. & Up to lower & Upper sec. & Years of \\
degree & sec. degree & degree & education \\
\hline
\end{tabular}

Panel A: Linear age at migration indicator

\begin{tabular}{lrrrr} 
Age mig./10 & 0.143 & 0.342 & -0.058 & 0.303 \\
& $(0.166)$ & $(0.275)$ & $(0.081)$ & $(0.766)$ \\
\hline
\end{tabular}

\section{Panel B: Quadratic age at migration indicators}

\begin{tabular}{lcccr} 
Age mig./10 & $0.403 *$ & $1.240 * * *$ & -0.001 & -1.460 \\
& $(0.331)$ & $(0.424)$ & $(0.238)$ & $(1.530)$ \\
Age mig. ${ }^{2} / 100$ & -0.144 & $-0.497 * *$ & -0.031 & 0.975 \\
& $(0.124)$ & $(0.195)$ & $(0.107)$ & $(0.737)$ \\
\hline F-Test p-value & 0.471 & $0.016 * *$ & 0.628 & 0.393 \\
\hline
\end{tabular}

\section{Panel C: Categorical age at migration indicators}

\begin{tabular}{lcccc} 
Age mig. 3-5 & 0.164 & $0.315 *$ & $-0.234 * *$ & -0.977 \\
& $(0.117)$ & $(0.158)$ & $(0.109)$ & $(0.631)$ \\
Age mig. 6-8 & $0.313 * *$ & $0.645 * * *$ & $-0.226 *$ & $-1.408 *$ \\
& $(0.154)$ & $(0.194)$ & $(0.129)$ & $(0.777)$ \\
Age mig. 9-11 & $0.385 * *$ & $0.622 * * *$ & -0.223 & -1.148 \\
& $(0.188)$ & $(0.233)$ & $(0.138)$ & $(0.858)$ \\
Age mig. 12-14 & $0.412 *$ & $0.774 * * *$ & -0.236 & -0.823 \\
& $(0.216)$ & $(0.257)$ & $(0.146)$ & $(0.933)$ \\
Age mig. 15-17 & $0.510 * *$ & $0.802 * *$ & $-0.388 * *$ & -1.541 \\
& $(0.244)$ & $(0.331)$ & $(0.178)$ & $(1.148)$ \\
\hline F-Test p-value & 0.352 & $0.024 * *$ & 0.231 & 0.343 \\
\hline Note: Dependent variables as specified. Robust & standard errors & are in parentheses. Additional \\
explanatory variables: female, firstborn, and a constant. These estimations do not control for year of \\
immigration because it is identical between siblings. Number of observations: 167. Significance level: \\
$*<0.1$, **<0.05, ***<0.01. \\
Source: SOEP (1984-2013), own calculations.
\end{tabular}


Table 8 Fixed Effects Estimation Results - Interactions for Firstborn

\begin{tabular}{|c|c|c|c|c|}
\hline & $\begin{array}{c}\text { No sec. } \\
\text { degree }\end{array}$ & $\begin{array}{l}\text { Up to lower } \\
\text { sec. degree }\end{array}$ & $\begin{array}{c}\text { Upper sec. } \\
\text { degree }\end{array}$ & $\begin{array}{c}\text { Years of } \\
\text { education }\end{array}$ \\
\hline \multicolumn{5}{|c|}{ Panel A: Linear age at migration indicator } \\
\hline Age mig./10 & $\begin{array}{r}0.191 \\
(0.116)\end{array}$ & $\begin{array}{l}0.291 * \\
(0.153)\end{array}$ & $\begin{array}{r}-0.033 \\
(0.039)\end{array}$ & $\begin{array}{c}-0.662 \\
(0.477)\end{array}$ \\
\hline Age mig./10*Firstborn & $\begin{array}{r}-0.061 \\
(0.088)\end{array}$ & $\begin{array}{r}-0.091 \\
(0.103)\end{array}$ & $\begin{array}{r}-0.053 \\
(0.038)\end{array}$ & $\begin{array}{r}-0.085 \\
(0.337)\end{array}$ \\
\hline Firstborn & $\begin{array}{r}0.022 \\
(0.107) \\
\end{array}$ & $\begin{array}{r}0.006 \\
(0.127) \\
\end{array}$ & $\begin{array}{r}0.078 \\
(0.048) \\
\end{array}$ & $\begin{array}{r}0.277 \\
(0.412) \\
\end{array}$ \\
\hline \multicolumn{5}{|c|}{ Panel B: Quadratic age at migration indicators } \\
\hline Age mig./10 & $\begin{array}{r}0.421 \\
(0.306)\end{array}$ & $\begin{array}{r}0.386 \\
(0.343)\end{array}$ & $\begin{array}{l}-0.162 * \\
(0.092)\end{array}$ & $\begin{array}{l}-2.278 * \\
(1.284)\end{array}$ \\
\hline Age mig./10*Firstborn & $\begin{array}{r}0.064 \\
(0.461)\end{array}$ & $\begin{array}{r}0.628 \\
(0.573)\end{array}$ & $\begin{array}{r}0.100 \\
(0.139)\end{array}$ & $\begin{array}{r}0.826 \\
(1.784)\end{array}$ \\
\hline Age mig. ${ }^{2} / 100$ & $\begin{array}{l}-0.143 \\
(0.176)\end{array}$ & $\begin{array}{r}-0.060 \\
(0.204)\end{array}$ & $\begin{array}{r}0.080 \\
(0.049)\end{array}$ & $\begin{array}{r}1.002 \\
(0.680)\end{array}$ \\
\hline Age mig. ${ }^{2} / 100 *$ Firstborn & $\begin{array}{l}-0.033 \\
(0.241)\end{array}$ & $\begin{array}{l}-0.356 \\
(0.307)\end{array}$ & $\begin{array}{r}-0.096 \\
(0.081)\end{array}$ & $\begin{array}{l}-0.686 \\
(0.965)\end{array}$ \\
\hline Firstborn & $\begin{array}{r}-0.058 \\
(0.219) \\
\end{array}$ & $\begin{array}{r}-0.287 \\
(0.240)\end{array}$ & $\begin{array}{r}0.036 \\
(0.061) \\
\end{array}$ & $\begin{array}{r}0.148 \\
(0.746) \\
\end{array}$ \\
\hline F test $\mathrm{p}$-value - main & 0.194 & 0.154 & 0.213 & 0.188 \\
\hline F test p-value - Firstborn & 0.990 & 0.504 & 0.152 & 0.462 \\
\hline \multicolumn{5}{|c|}{ Panel C: Categorical age at migration indicators } \\
\hline Age mig. 3-5 & $\begin{array}{r}0.120 \\
(0.078)\end{array}$ & $\begin{array}{r}0.132 \\
(0.099)\end{array}$ & $\begin{array}{l}-0.144 * * \\
(0.072)\end{array}$ & $\begin{array}{r}-0.489 \\
(0.416)\end{array}$ \\
\hline Age mig. 6-8 & $\begin{array}{r}0.197 \\
(0.119)\end{array}$ & $\begin{array}{l}0.296 * * \\
(0.136)\end{array}$ & $\begin{array}{l}-0.151 * * \\
(0.071)\end{array}$ & $\begin{array}{r}-0.768 \\
(0.539)\end{array}$ \\
\hline Age mig. 9-11 & $\begin{array}{l}0.271 * * \\
(0.117)\end{array}$ & $\begin{array}{l}0.366 \text { ** } \\
(0.150)\end{array}$ & $\begin{array}{l}-0.156 * * \\
(0.075)\end{array}$ & $\begin{array}{l}-1.337 * * \\
(0.542)\end{array}$ \\
\hline Age mig. 12-14 & $\begin{array}{c}0.253 * \\
(0.137)\end{array}$ & $\begin{array}{l}0.454 * * * \\
(0.169)\end{array}$ & $\begin{array}{l}-0.148 * \\
(0.079)\end{array}$ & $\begin{array}{l}-0.673 \\
(0.603)\end{array}$ \\
\hline Age mig. $15-17$ & $\begin{array}{r}0.468 \\
(0.256)\end{array}$ & $\begin{array}{c}0.691 * * \\
(0.272)\end{array}$ & $\begin{array}{l}-0.211 * * \\
(0.103)\end{array}$ & $\begin{array}{l}-1.901 * * \\
(0.817)\end{array}$ \\
\hline Age mig. $3-5 *$ Firstborn & $\begin{array}{l}0.543 * * \\
(0.215)\end{array}$ & $\begin{array}{r}0.337 \\
(0.271)\end{array}$ & $\begin{array}{c}0.198 * \\
(0.107)\end{array}$ & $\begin{array}{l}-1.236 * \\
(0.734)\end{array}$ \\
\hline Age mig. 6-8*Firstborn & $\begin{array}{c}0.489 * * \\
(0.226)\end{array}$ & $\begin{array}{l}0.493 * \\
(0.258)\end{array}$ & $\begin{array}{r}0.085 \\
(0.053)\end{array}$ & $\begin{array}{l}-1.572 * * \\
(0.706)\end{array}$ \\
\hline Age mig. 9-11*Firstborn & $\begin{array}{r}0.374 \\
(0.227)\end{array}$ & $\begin{array}{r}0.377 \\
(0.273)\end{array}$ & $\begin{array}{r}0.051 \\
(0.050)\end{array}$ & $\begin{array}{l}-0.798 \\
(0.726)\end{array}$ \\
\hline Age mig. $12-14^{*}$ Firstborn & $\begin{array}{l}0.471 * * \\
(0.212)\end{array}$ & $\begin{array}{r}0.356 \\
(0.254)\end{array}$ & $\begin{array}{r}0.027 \\
(0.037)\end{array}$ & $\begin{array}{l}-1.814 * * * \\
(0.630)\end{array}$ \\
\hline Age mig. $15-17^{*}$ Firstborn & $\begin{array}{r}0.307 \\
(0.290)\end{array}$ & $\begin{array}{r}0.148 \\
(0.310)\end{array}$ & $\begin{array}{r}0.045 \\
(0.060)\end{array}$ & $\begin{array}{r}-0.933 \\
(0.778)\end{array}$ \\
\hline Firstborn & $\begin{array}{l}-0.481 * * \\
(0.203)\end{array}$ & $\begin{array}{l}-0.465 * * \\
(0.234)\end{array}$ & $\begin{array}{r}-0.025 \\
(0.031)\end{array}$ & $\begin{array}{l}1.546 * * * \\
(0.557)\end{array}$ \\
\hline F test $\mathrm{p}$-value - main & 0.294 & 0.149 & 0.350 & $0.030 * *$ \\
\hline F test p-value - Firstborn & 0.153 & 0.455 & 0.352 & $0.068 *$ \\
\hline
\end{tabular}

Note: Dependent variables as specified. Robust standard errors are in parentheses. Additional explanatory variables: female, year of immigration, and a constant. F test p-value - main shows the pvalue of the joint significance test for age at migration indicators without interactions, $F$ test $p$-value FB shows the p-value of the joint significance test for age at migration indicators with firstborn interaction effects. Number of observations: 348. Significance level: $*<0.1, * *<0.05, * * *<0.01$. Source: SOEP (1984-2013), own calculations. 
Table 9 Fixed Effects Estimation Results - Adding Native and Second Generation Immigrant Observations to Identify a Secular Trend

\begin{tabular}{lcccc}
\hline & $\begin{array}{c}\text { No sec. } \\
\text { degree }\end{array}$ & $\begin{array}{c}\text { Up to lower } \\
\text { sec. degree }\end{array}$ & $\begin{array}{c}\text { Upper sec. } \\
\text { degree }\end{array}$ & $\begin{array}{c}\text { Years of } \\
\text { education }\end{array}$ \\
\hline Panel A: Linear age at migration indicator & & & \\
Age mig./10 & $0.094 *$ & $0.175 * * *$ & -0.072 & $-0.753 * * *$ \\
& $(0.053)$ & $(0.058)$ & $(0.044)$ & $(0.238)$ \\
Year of birth/1000 & $-2.373 *$ & $-9.967 * * *$ & $7.440 * * *$ & $26.952 * * *$ \\
& $(1.364)$ & $(2.645)$ & $(2.288)$ & $(9.541)$ \\
\hline
\end{tabular}

\section{Panel B: Quadratic age at migration indicators}

\begin{tabular}{lcccc} 
Age mig./10 & -0.195 & $0.386 * *$ & $-0.221 *$ & -0.622 \\
& $(0.155)$ & $(0.169)$ & $(0.124)$ & $(0.735)$ \\
Age mig. ${ }^{2} / 100$ & $0.171 *$ & -0.125 & 0.088 & -0.077 \\
& $(0.090)$ & $(0.096)$ & $(0.067)$ & $(0.408)$ \\
Year of birth/1000 & $-2.499 *$ & $-9.874 * * *$ & $7.374 * * *$ & $27.010 * * *$ \\
& $(1.351)$ & $(2.653)$ & $(2.290)$ & $(9.548)$ \\
\hline F-Test p-value & $0.045 * *$ & $0.004 * * *$ & 0.126 & $0.006 * * *$ \\
\hline
\end{tabular}

\section{Panel C: Categorical age at migration indicators}

\begin{tabular}{|c|c|c|c|c|}
\hline Age mig. 0-2 & $\begin{array}{r}0.032 \\
(0.056)\end{array}$ & $\begin{array}{r}0.064 \\
(0.062)\end{array}$ & $\begin{array}{r}0.016 \\
(0.051)\end{array}$ & $\begin{array}{l}-0.120 \\
(0.297)\end{array}$ \\
\hline Age mig. 3-5 & $\begin{array}{r}0.041 \\
(0.045)\end{array}$ & $\begin{array}{r}0.072 \\
(0.063)\end{array}$ & $\begin{array}{r}-0.020 \\
(0.040)\end{array}$ & $\begin{array}{l}-0.263 \\
(0.227)\end{array}$ \\
\hline Age mig. 6-8 & $\begin{array}{r}0.050 \\
(0.043)\end{array}$ & $\begin{array}{l}0.218 * * * \\
(0.063)\end{array}$ & $\begin{array}{l}-0.102 * * \\
(0.046)\end{array}$ & $\begin{array}{l}-0.601 * * \\
(0.234)\end{array}$ \\
\hline Age mig. 9-11 & $\begin{array}{r}0.068 \\
(0.043)\end{array}$ & $\begin{array}{l}0.236 \text { *** } \\
(0.056)\end{array}$ & $\begin{array}{l}-0.103 * * \\
(0.049)\end{array}$ & $\begin{array}{l}-0.827 * * * \\
(0.207)\end{array}$ \\
\hline Age mig. 12-14 & $\begin{array}{r}0.047 \\
(0.047)\end{array}$ & $\begin{array}{l}0.208 * * * \\
(0.059)\end{array}$ & $\begin{array}{r}-0.063 \\
(0.051)\end{array}$ & $\begin{array}{l}-0.464 * * \\
(0.232)\end{array}$ \\
\hline Age mig. $15-17$ & $\begin{array}{l}0.269 * * * \\
(0.078)\end{array}$ & $\begin{array}{l}0.271 * * * \\
(0.073)\end{array}$ & $\begin{array}{l}-0.132 * * \\
(0.054)\end{array}$ & $\begin{array}{l}-1.481 * * * \\
(0.302)\end{array}$ \\
\hline Year of birth/1000 & $\begin{array}{l}-2.902 * * \\
(1.149)\end{array}$ & $\begin{array}{c}-11.743 * * * \\
(2.266)\end{array}$ & $\begin{array}{l}7.349 * * * \\
(2.107)\end{array}$ & $\begin{array}{l}31.709 * * * \\
(8.366)\end{array}$ \\
\hline F-Test p-value & $0.049 * *$ & $0.000 * * *$ & $0.096 *$ & $0.000 * * *$ \\
\hline $\begin{array}{l}\text { Note: Dependent } \\
\text { explanatory variable } \\
\text { (not panel C), and } \\
* * *<0.01 \text {. }\end{array}$ & $\begin{array}{l}\text { cified. Ro } \\
\text { rn, year of } \\
\text { aber of ob }\end{array}$ & indard & 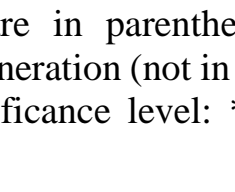 & $\begin{array}{l}\text { Additional } \\
\text { el C), native } \\
1, * *<0.05 \text {, }\end{array}$ \\
\hline
\end{tabular}




\section{Appendix}

Table A.1 Descriptive Statistics of Covariates

\begin{tabular}{|c|c|c|c|c|c|c|}
\hline & \multicolumn{2}{|c|}{ Total } & \multicolumn{2}{|c|}{ Males } & \multicolumn{2}{|c|}{ Females } \\
\hline & Mean & Std. Dev. & Mean & Std. Dev. & Mean & Std. Dev. \\
\hline \multicolumn{7}{|l|}{ Age at migration } \\
\hline Age at migration & 8.471 & 4.573 & 8.513 & 4.522 & 8.420 & 4.648 \\
\hline Age mig. 0-2 & 0.103 & 0.305 & 0.089 & 0.285 & 0.121 & 0.327 \\
\hline Age mig. 3-5 & 0.210 & 0.408 & 0.225 & 0.419 & 0.191 & 0.394 \\
\hline Age mig. 6-8 & 0.198 & 0.399 & 0.199 & 0.400 & 0.197 & 0.399 \\
\hline Age mig. 9-11 & 0.195 & 0.397 & 0.178 & 0.384 & 0.217 & 0.413 \\
\hline Age mig. 12-14 & 0.193 & 0.395 & 0.220 & 0.415 & 0.159 & 0.367 \\
\hline Age mig. $15-17$ & 0.101 & 0.301 & 0.089 & 0.285 & 0.115 & 0.320 \\
\hline Year of migration & 1980.026 & 7.545 & 1979.565 & 7.137 & 1980.586 & 8.000 \\
\hline Year of birth & 1971.555 & 6.838 & 1971.052 & 6.542 & 1972.166 & 7.156 \\
\hline Survey Year & 1992.555 & 6.838 & 1992.052 & 6.542 & 1993.166 & 7.156 \\
\hline Parents university & 0.055 & 0.228 & 0.031 & 0.175 & 0.083 & 0.276 \\
\hline Firstborn & 0.417 & 0.494 & 0.398 & 0.491 & 0.439 & 0.498 \\
\hline \multicolumn{7}{|l|}{ Region of origin } \\
\hline Western Europe & 0.121 & 0.326 & 0.110 & 0.314 & 0.134 & 0.341 \\
\hline Eastern Europe & 0.296 & 0.457 & 0.277 & 0.449 & 0.318 & 0.467 \\
\hline Turkey & 0.494 & 0.501 & 0.545 & 0.499 & 0.433 & 0.497 \\
\hline Non-Europe & 0.089 & 0.285 & 0.068 & 0.253 & 0.115 & 0.320 \\
\hline \multicolumn{7}{|l|}{ Federal states } \\
\hline Schleswig-Holstein & 0.017 & 0.130 & 0.010 & 0.102 & 0.025 & 0.158 \\
\hline Hamburg & 0.014 & 0.119 & 0.016 & 0.125 & 0.013 & 0.113 \\
\hline Niedersachsen & 0.109 & 0.312 & 0.126 & 0.332 & 0.089 & 0.286 \\
\hline Bremen & 0.011 & 0.107 & 0.016 & 0.125 & 0.006 & 0.080 \\
\hline Nordrhein-Westfalen & 0.273 & 0.446 & 0.267 & 0.444 & 0.280 & 0.451 \\
\hline Hessen & 0.115 & 0.319 & 0.105 & 0.307 & 0.127 & 0.334 \\
\hline Rheinland-Pf./Saarland & 0.069 & 0.254 & 0.058 & 0.234 & 0.083 & 0.276 \\
\hline Baden-Württemberg & 0.218 & 0.414 & 0.220 & 0.415 & 0.217 & 0.413 \\
\hline Bayern & 0.126 & 0.333 & 0.136 & 0.344 & 0.115 & 0.320 \\
\hline Berlin & 0.040 & 0.197 & 0.047 & 0.212 & 0.032 & 0.176 \\
\hline Meck.-Vorpommern & 0.006 & 0.076 & 0.000 & 0.000 & 0.013 & 0.113 \\
\hline $\mathrm{N}$ & 348 & & 191 & & 157 & \\
\hline \multicolumn{7}{|l|}{ Language ability } \\
\hline Very low & 0.040 & 0.196 & 0.042 & 0.201 & 0.037 & 0.190 \\
\hline Low & 0.139 & 0.347 & 0.108 & 0.311 & 0.178 & 0.384 \\
\hline Medium & 0.447 & 0.498 & 0.479 & 0.501 & 0.407 & 0.493 \\
\hline High & 0.374 & 0.485 & 0.371 & 0.485 & 0.378 & 0.487 \\
\hline $\mathrm{N}$ & 302 & & 167 & & 135 & \\
\hline
\end{tabular}

Source: SOEP (1984-2013), own calculations. 
Table A.2 Least Squares Estimation Results - using the Full Sample of First Generation Immigrants

\begin{tabular}{cccc}
$\begin{array}{c}\text { No sec. } \\
\text { degree }\end{array}$ & $\begin{array}{c}\text { Up to lower } \\
\text { sec. degree }\end{array}$ & $\begin{array}{c}\text { Upper sec. } \\
\text { degree }\end{array}$ & $\begin{array}{c}\text { Years of } \\
\text { education }\end{array}$ \\
\hline
\end{tabular}

Panel A: Linear age at migration indicator

\begin{tabular}{lcccc} 
Age mig./10 & $0.083 * *$ & $0.195 * * *$ & $-0.082 * * *$ & $-0.651 * * *$ \\
& $(0.033)$ & $(0.037)$ & $(0.026)$ & $(0.147)$ \\
\hline
\end{tabular}

\section{Panel B: Quadratic age at migration indicator}

\begin{tabular}{lcccc} 
& $-0.393 * * *$ & 0.075 & -0.124 & 0.577 \\
Age mig./10 & $(0.119)$ & $(0.126)$ & $(0.089)$ & $(0.529)$ \\
Age mig. ${ }^{2} / 100$ & $0.285 * * *$ & 0.072 & 0.026 & $-0.736 * *$ \\
& $(0.069)$ & $(0.071)$ & $(0.047)$ & $(0.297)$ \\
\hline F-Test p-value & $0.000 * * *$ & $0.000 * * *$ & $0.008 * * *$ & $0.000 * * *$ \\
\hline \multirow{5}{*}{ Panel C: Categorical age at migration indicators } & & \\
Age mig. 3-5 & -0.070 & -0.033 & -0.039 & 0.141 \\
& $(0.047)$ & $(0.057)$ & $(0.042)$ & $(0.236)$ \\
Age mig. 6-8 & -0.058 & 0.060 & $-0.071 *$ & -0.103 \\
& $(0.047)$ & $(0.057)$ & $(0.042)$ & $(0.231)$ \\
Age mig. 9-11 & -0.042 & $0.155 * * *$ & $-0.114 * * *$ & -0.383 \\
& $(0.049)$ & $(0.057)$ & $(0.041)$ & $(0.234)$ \\
Age mig. 12-14 & -0.020 & $0.141 * *$ & $-0.089 * *$ & -0.199 \\
& $(0.052)$ & $(0.059)$ & $(0.042)$ & $(0.239)$ \\
Age mig. 15-17 & $0.194 * * *$ & $0.283 * * *$ & $-0.137 * * *$ & $-1.263 * * *$ \\
& $(0.067)$ & $(0.067)$ & $(0.042)$ & $(0.268)$ \\
\hline F-Test p-value & $0.000 * * *$ & $0.000 * * *$ & $0.014 * *$ & $0.000 * * *$ \\
\hline
\end{tabular}

Note: Dependent variables as specified. Robust standard errors are shown in parentheses. Additional explanatory variables: female, firstborn, region of origin, parental education, year of immigration, federal state, and a constant. Number of observations: 774. Significance level: $*<0.1, * *<0.05$, $* * *<0.01$.

Source: SOEP (1984-2013), own calculations. 
Table A.3 Fixed Effects Estimation Results by Gender and Country of Origin (Turkish vs. non-Turkish)

\begin{tabular}{|c|c|c|c|c|c|c|c|c|}
\hline & \multicolumn{4}{|c|}{ Migrants from Turkey } & \multicolumn{4}{|c|}{ Migrants from other countries } \\
\hline & $\begin{array}{c}\text { No sec. } \\
\text { degree }\end{array}$ & $\begin{array}{l}\text { Up to lower } \\
\text { sec. degree }\end{array}$ & $\begin{array}{l}\text { Upper sec. } \\
\text { degree }\end{array}$ & $\begin{array}{c}\text { Years of } \\
\text { education }\end{array}$ & $\begin{array}{c}\begin{array}{c}\text { No sec. } \\
\text { degree }\end{array} \\
\end{array}$ & $\begin{array}{l}\text { Up to lower } \\
\text { sec. degree }\end{array}$ & $\begin{array}{c}\text { Upper sec. } \\
\text { degree }\end{array}$ & $\begin{array}{c}\text { Years of } \\
\text { education }\end{array}$ \\
\hline \multicolumn{9}{|c|}{ Panel A: Linear age at migration indicator } \\
\hline Age mig. $/ 10 *$ fem & $\begin{array}{r}0.124 \\
(0.231)\end{array}$ & $\begin{array}{r}-0.000 \\
(0.195)\end{array}$ & $\begin{array}{l}-0.032 \\
(0.031)\end{array}$ & $\begin{array}{l}-1.158 \\
(0.789)\end{array}$ & $\begin{array}{c}0.214 \text { * } \\
(0.124)\end{array}$ & $\begin{array}{c}0.62 \text { ** } \\
(0.244)\end{array}$ & $\begin{array}{r}-0.119 \\
(0.084)\end{array}$ & $\begin{array}{r}-0.764 \\
(0.626)\end{array}$ \\
\hline Age mig./10*male & $\begin{array}{r}0.067 \\
(0.206)\end{array}$ & $\begin{array}{l}-0.008 \\
(0.200)\end{array}$ & $\begin{array}{l}-0.044 \\
(0.042)\end{array}$ & $\begin{array}{l}-0.474 \\
(0.822)\end{array}$ & $\begin{array}{l}0.327 * * \\
(0.143)\end{array}$ & $\begin{array}{c}0.429 * \\
(0.218)\end{array}$ & $\begin{array}{r}0.050 \\
(0.072)\end{array}$ & $\begin{array}{r}-0.289 \\
(0.656)\end{array}$ \\
\hline Female & $\begin{array}{r}0.088 \\
(0.202) \\
\end{array}$ & $\begin{array}{r}-0.105 \\
(0.139) \\
\end{array}$ & $\begin{array}{r}-0.012 \\
(0.012) \\
\end{array}$ & $\begin{array}{r}0.272 \\
(0.570) \\
\end{array}$ & $\begin{array}{r}0.134 \\
(0.085) \\
\end{array}$ & $\begin{array}{l}-0.324 * * \\
(0.159)\end{array}$ & $\begin{array}{l}0.159 * * \\
(0.090)\end{array}$ & $\begin{array}{r}0.437 \\
(0.477) \\
\end{array}$ \\
\hline \multicolumn{9}{|c|}{ Panel B: Quadratic age at migration indicators } \\
\hline Age mig. $/ 10 *$ fem & $\begin{array}{r}0.727 \\
(0.509)\end{array}$ & $\begin{array}{r}0.551 \\
(0.413)\end{array}$ & $\begin{array}{l}-0.031 \\
(0.032)\end{array}$ & $\begin{array}{l}-1.577 \\
(1.923)\end{array}$ & $\begin{array}{c}0.636 * \\
(0.332)\end{array}$ & $\begin{array}{l}0.977 \text { * } \\
(0.535)\end{array}$ & $\begin{array}{l}-0.313 \\
(0.270)\end{array}$ & $\begin{array}{r}-3.192 \\
(1.978)\end{array}$ \\
\hline Age mig./10*male & $\begin{array}{l}-0.069 \\
(0.557)\end{array}$ & $\begin{array}{r}0.196 \\
(0.505)\end{array}$ & $\begin{array}{l}-0.055 \\
(0.050)\end{array}$ & $\begin{array}{l}-2.475 \\
(1.746)\end{array}$ & $\begin{array}{r}0.410 \\
(0.277)\end{array}$ & $\begin{array}{r}0.706 \\
(0.465)\end{array}$ & $\begin{array}{r}0.204 \\
(0.173)\end{array}$ & $\begin{array}{r}0.365 \\
(1.353)\end{array}$ \\
\hline Age mig. ${ }^{2} / 100 *$ fem & $\begin{array}{l}-0.358 \\
(0.275)\end{array}$ & $\begin{array}{l}-0.312 \\
(0.189)\end{array}$ & $\begin{array}{l}-0.001 \\
(0.007)\end{array}$ & $\begin{array}{r}0.151 \\
(0.982)\end{array}$ & $\begin{array}{l}-0.239 \\
(0.148)\end{array}$ & $\begin{array}{l}-0.209 \\
(0.273)\end{array}$ & $\begin{array}{r}0.099 \\
(0.126)\end{array}$ & $\begin{array}{r}1.314 \\
(0.897)\end{array}$ \\
\hline Age mig. ${ }^{2} / 100 *$ male & $\begin{array}{r}0.063 \\
(0.296)\end{array}$ & $\begin{array}{l}-0.120 \\
(0.252)\end{array}$ & $\begin{array}{r}0.005 \\
(0.010)\end{array}$ & $\begin{array}{r}1.092 \\
(0.883)\end{array}$ & $\begin{array}{l}-0.048 \\
(0.134)\end{array}$ & $\begin{array}{l}-0.178 \\
(0.274)\end{array}$ & $\begin{array}{l}-0.105 \\
(0.093)\end{array}$ & $\begin{array}{r}-0.473 \\
(0.754)\end{array}$ \\
\hline Female & $\begin{array}{l}-0.147 \\
(0.253) \\
\end{array}$ & $\begin{array}{r}-0.226 \\
(0.278) \\
\end{array}$ & $\begin{array}{r}-0.015 \\
(0.015) \\
\end{array}$ & $\begin{array}{c}-0.163 \\
(0.779) \\
\end{array}$ & $\begin{array}{r}0.017 \\
(0.127) \\
\end{array}$ & $\begin{array}{r}-0.366 \\
(0.241) \\
\end{array}$ & $\begin{array}{c}0.265 * \\
(0.147) \\
\end{array}$ & $\begin{array}{c}1.417 * \\
(0.785) \\
\end{array}$ \\
\hline F test p-value - fem. & 0.366 & 0.248 & 0.581 & 0.2314 & 0.1589 & $0.048 * *$ & 0.281 & 0.273 \\
\hline F test p-value - males & 0.956 & 0.885 & 0.555 & 0.3703 & $0.0963 *$ & 0.122 & 0.499 & 0.725 \\
\hline \multicolumn{9}{|c|}{ Panel C: Categorical age at migration indicators } \\
\hline Age mig. $3-5 *$ fem & $\begin{array}{c}0.480 * \\
(0.240)\end{array}$ & $\begin{array}{r}0.274 \\
(0.204)\end{array}$ & $\begin{array}{l}-0.022 \\
(0.021)\end{array}$ & $\begin{array}{l}-1.538 * * \\
(0.715)\end{array}$ & $\begin{array}{c}0.194 \text { * } \\
(0.105)\end{array}$ & $\begin{array}{l}0.397 \text { ** } \\
(0.165)\end{array}$ & $\begin{array}{l}-0.132 \\
(0.099)\end{array}$ & $\begin{array}{l}-1.335 * \\
(0.733)\end{array}$ \\
\hline Age mig. 6-8*fem & $\begin{array}{c}0.554 * \\
(0.288)\end{array}$ & $\begin{array}{l}0.4611^{* *} \\
(0.197)\end{array}$ & $\begin{array}{l}-0.027 \\
(0.025)\end{array}$ & $\begin{array}{l}-1.197 \\
(0.896)\end{array}$ & $\begin{array}{l}0.364 \text { ** } \\
(0.179)\end{array}$ & $\begin{array}{l}0.819 * * * \\
(0.226)\end{array}$ & $\begin{array}{l}-0.351 * \\
(0.177)\end{array}$ & $\begin{array}{l}-2.431 * * \\
(1.035)\end{array}$ \\
\hline Age mig. $9-11 *$ fem & $\begin{array}{l}0.484 * * \\
(0.214)\end{array}$ & $\begin{array}{r}0.258 \\
(0.238)\end{array}$ & $\begin{array}{l}-0.046 \\
(0.041)\end{array}$ & $\begin{array}{l}-1.564 * * \\
(0.710)\end{array}$ & $\begin{array}{l}0.356 * * \\
(0.163)\end{array}$ & $\begin{array}{l}0.759 * * * \\
(0.275)\end{array}$ & $\begin{array}{l}-0.245 * \\
(0.134)\end{array}$ & $\begin{array}{l}-2.239 * * \\
(0.948)\end{array}$ \\
\hline Age mig. $12-14 *$ fem & $\begin{array}{r}0.286 \\
(0.265)\end{array}$ & $\begin{array}{r}0.329 \\
(0.230)\end{array}$ & $\begin{array}{l}-0.054 \\
(0.048)\end{array}$ & $\begin{array}{l}-1.340 \\
(0.902)\end{array}$ & $\begin{array}{l}0.502 \text { ** } \\
(0.209)\end{array}$ & $\begin{array}{l}1.023 \text { *** } \\
(0.299)\end{array}$ & $\begin{array}{l}-0.282 * \\
(0.143)\end{array}$ & $\begin{array}{l}-2.2022^{* *} \\
(1.041)\end{array}$ \\
\hline Age mig. $15-17 *$ fem & $\begin{array}{c}0.682 * \\
(0.388)\end{array}$ & $\begin{array}{r}0.404 \\
(0.285)\end{array}$ & $\begin{array}{l}-0.076 \\
(0.067)\end{array}$ & $\begin{array}{l}-3.167 * * * \\
(1.188)\end{array}$ & $\begin{array}{l}0.375 \text { ** } \\
(0.186)\end{array}$ & $\begin{array}{l}1.277 \text { *** } \\
(0.357)\end{array}$ & $\begin{array}{l}-0.410 * * \\
(0.173)\end{array}$ & $\begin{array}{l}-2.849 * * \\
(1.157)\end{array}$ \\
\hline Age mig. $3-5 *$ male & $\begin{array}{r}0.086 \\
(0.221)\end{array}$ & $\begin{array}{l}-0.090 \\
(0.145)\end{array}$ & $\begin{array}{r}0.005 \\
(0.009)\end{array}$ & $\begin{array}{r}0.376 \\
(0.691)\end{array}$ & $\begin{array}{r}0.160 \\
(0.121)\end{array}$ & $\begin{array}{r}0.078 \\
(0.167)\end{array}$ & $\begin{array}{l}-0.219 * * \\
(0.098)\end{array}$ & $\begin{array}{r}-0.450 \\
(0.556)\end{array}$ \\
\hline Age mig. $6-8 *$ male & $\begin{array}{r}0.147 \\
(0.260)\end{array}$ & $\begin{array}{r}-0.050 \\
(0.220)\end{array}$ & $\begin{array}{l}-0.042 \\
(0.037)\end{array}$ & $\begin{array}{l}-0.460 \\
(0.911)\end{array}$ & $\begin{array}{c}0.239 * \\
(0.127)\end{array}$ & $\begin{array}{l}0.346 \text { ** } \\
(0.164)\end{array}$ & $\begin{array}{r}-0.045 \\
(0.057)\end{array}$ & $\begin{array}{r}-0.469 \\
(0.601)\end{array}$ \\
\hline Age mig. $9-11 *$ male & $\begin{array}{r}0.251 \\
(0.301)\end{array}$ & $\begin{array}{r}0.267 \\
(0.243)\end{array}$ & $\begin{array}{l}-0.087 \\
(0.076)\end{array}$ & $\begin{array}{l}-1.546 \\
(1.017)\end{array}$ & $\begin{array}{r}0.259 \\
(0.175)\end{array}$ & $\begin{array}{l}0.348 \text { ** } \\
(0.170)\end{array}$ & $\begin{array}{l}-0.067 \\
(0.075)\end{array}$ & $\begin{array}{r}-0.180 \\
(0.644)\end{array}$ \\
\hline Age mig. $12-14 *$ male & $\begin{array}{r}0.193 \\
(0.319)\end{array}$ & $\begin{array}{r}0.091 \\
(0.261)\end{array}$ & $\begin{array}{l}-0.067 \\
(0.059)\end{array}$ & $\begin{array}{r}-0.657 \\
(1.107)\end{array}$ & $\begin{array}{l}0.548 * * * \\
(0.201)\end{array}$ & $\begin{array}{l}0.618 * * * \\
(0.229)\end{array}$ & $\begin{array}{l}-0.105 \\
(0.094)\end{array}$ & $\begin{array}{l}-1.021 \\
(0.765)\end{array}$ \\
\hline Age mig. $15-17 *$ male & $\begin{array}{r}0.421 \\
(0.364)\end{array}$ & $\begin{array}{r}-0.042 \\
(0.365)\end{array}$ & $\begin{array}{l}-0.079 \\
(0.070)\end{array}$ & $\begin{array}{l}-0.843 \\
(1.302)\end{array}$ & $\begin{array}{l}0.511 * * \\
(0.227)\end{array}$ & $\begin{array}{l}0.733 * * \\
(0.342)\end{array}$ & $\begin{array}{l}-0.235 * * \\
(0.111)\end{array}$ & $\begin{array}{l}-1.827 * \\
(1.032)\end{array}$ \\
\hline Female & $\begin{array}{c}-0.128 \\
(0.251) \\
\end{array}$ & $\begin{array}{r}-0.380 \\
(0.234) \\
\end{array}$ & $\begin{array}{l}-0.007 \\
(0.009) \\
\end{array}$ & $\begin{array}{r}0.706 \\
(0.688) \\
\end{array}$ & $\begin{array}{c}-0.002 \\
(0.129) \\
\end{array}$ & $\begin{array}{l}-0.541 \text { *** } \\
(0.186)\end{array}$ & $\begin{array}{r}0.149 \\
(0.107) \\
\end{array}$ & $\begin{array}{c}1.383 * \\
(0.711) \\
\end{array}$ \\
\hline F test p-value - fem. & $0.024 * *$ & $0.082 *$ & 0.9342 & $0.056 *$ & 0.300 & $0.007 * * *$ & 0.301 & 0.191 \\
\hline F test p-value - males & 0.812 & 0.165 & 0.9283 & $0.050 *$ & 0.156 & 0.137 & 0.202 & 0.498 \\
\hline
\end{tabular}


Table A.4 Fixed Effects Estimation Results - First and Second Generation Immigrants Separately Estimated by Sibling Gender

\begin{tabular}{|c|c|c|c|c|c|c|c|c|}
\hline & \multicolumn{4}{|c|}{ Females } & \multicolumn{4}{|c|}{ Males } \\
\hline & $\begin{array}{c}\text { No sec. } \\
\text { degree }\end{array}$ & $\begin{array}{l}\text { Up to lower } \\
\text { sec. degree }\end{array}$ & $\begin{array}{c}\text { Upper sec. } \\
\text { degree }\end{array}$ & $\begin{array}{c}\text { Years of } \\
\text { education }\end{array}$ & $\begin{array}{c}\text { No sec. } \\
\text { degree }\end{array}$ & $\begin{array}{l}\text { Up to lower } \\
\text { sec. degree }\end{array}$ & $\begin{array}{c}\text { Upper sec. } \\
\text { degree }\end{array}$ & $\begin{array}{r}\text { Years of } \\
\text { education }\end{array}$ \\
\hline \multicolumn{9}{|c|}{ Panel A: Linear age at migration indicator } \\
\hline Age mig./10 & $\begin{array}{l}0.445 * * * \\
(0.100)\end{array}$ & $\begin{array}{r}0.174 \\
(0.115)\end{array}$ & $\begin{array}{r}-0.033 \\
(0.052)\end{array}$ & $\begin{array}{l}-1.350 * * * \\
(0.378)\end{array}$ & $\begin{array}{r}0.065 \\
(0.100)\end{array}$ & $\begin{array}{r}0.141 \\
(0.112)\end{array}$ & $\begin{array}{l}-0.095 \\
(0.071)\end{array}$ & $\begin{array}{l}-0.738 * \\
(0.415)\end{array}$ \\
\hline 2nd Generation & $\begin{array}{r}0.172 \\
(0.139)\end{array}$ & $\begin{array}{l}-0.053 \\
(0.131)\end{array}$ & $\begin{array}{r}0.059 \\
(0.076)\end{array}$ & $\begin{array}{l}-0.541 \\
(0.508)\end{array}$ & $\begin{array}{r}0.040 \\
(0.095)\end{array}$ & $\begin{array}{r}-0.025 \\
(0.091)\end{array}$ & $\begin{array}{r}0.034 \\
(0.056)\end{array}$ & $\begin{array}{r}-0.141 \\
(0.369)\end{array}$ \\
\hline \multicolumn{9}{|c|}{ Panel B: Quadratic age at migration indicators } \\
\hline Age mig./10 & $\begin{array}{r}0.298 \\
(0.371)\end{array}$ & $\begin{array}{r}0.330 \\
(0.299)\end{array}$ & $\begin{array}{c}-0.293 \\
(0.205)\end{array}$ & $\begin{array}{c}-1.772 \\
(1.485)\end{array}$ & $\begin{array}{r}0.016 \\
(0.288)\end{array}$ & $\begin{array}{l}0.735 * * * \\
(0.257)\end{array}$ & $\begin{array}{r}-0.141 \\
(0.131)\end{array}$ & $\begin{array}{r}-1.882 \\
(1.160)\end{array}$ \\
\hline Age mig. ${ }^{2} / 100$ & $\begin{array}{r}0.086 \\
(0.190)\end{array}$ & $\begin{array}{r}-0.091 \\
(0.154)\end{array}$ & $\begin{array}{r}-0.009 \\
(0.096)\end{array}$ & $\begin{array}{r}0.245 \\
(0.739)\end{array}$ & $\begin{array}{r}0.031 \\
(0.161)\end{array}$ & $\begin{array}{l}-0.373 * * \\
(0.150)\end{array}$ & $\begin{array}{r}0.029 \\
(0.079)\end{array}$ & $\begin{array}{r}0.720 \\
(0.665)\end{array}$ \\
\hline 2nd Generation & $\begin{array}{r}0.134 \\
(0.175) \\
\end{array}$ & $\begin{array}{r}-0.013 \\
(0.154) \\
\end{array}$ & $\begin{array}{r}0.151 \\
(0.099) \\
\end{array}$ & $\begin{array}{r}-0.651 \\
(0.666) \\
\end{array}$ & $\begin{array}{r}0.026 \\
(0.131) \\
\end{array}$ & $\begin{array}{r}0.136 \\
(0.102) \\
\end{array}$ & $\begin{array}{r}0.021 \\
(0.040) \\
\end{array}$ & $\begin{array}{r}-0.451 \\
(0.485) \\
\end{array}$ \\
\hline F-Test p-value & $0.000 * * *$ & 0.291 & 0.295 & $0.001 * * *$ & 0.777 & $0.018 * *$ & 0.334 & 0.130 \\
\hline \multicolumn{9}{|c|}{ Panel C: Categorical age at migration indicators } \\
\hline Age mig. 0-2 & $\begin{array}{r}-0.135 \\
(0.144)\end{array}$ & $\begin{array}{r}0.053 \\
(0.128)\end{array}$ & $\begin{array}{r}0.005 \\
(0.089)\end{array}$ & $\begin{array}{r}0.598 \\
(0.541)\end{array}$ & $\begin{array}{r}0.014 \\
(0.125)\end{array}$ & $\begin{array}{r}0.044 \\
(0.072)\end{array}$ & $\begin{array}{c}-0.039 \\
(0.030)\end{array}$ & $\begin{array}{r}-0.054 \\
(0.447)\end{array}$ \\
\hline Age mig. 3-5 & $\begin{array}{r}0.043 \\
(0.126)\end{array}$ & $\begin{array}{r}0.124 \\
(0.162)\end{array}$ & $\begin{array}{r}-0.068 \\
(0.046)\end{array}$ & $\begin{array}{l}-0.229 \\
(0.542)\end{array}$ & $\begin{array}{r}-0.026 \\
(0.081)\end{array}$ & $\begin{array}{r}0.010 \\
(0.100)\end{array}$ & $\begin{array}{r}-0.062 \\
(0.083)\end{array}$ & $\begin{array}{r}0.020 \\
(0.382)\end{array}$ \\
\hline Age mig. 6-8 & $\begin{array}{r}0.282 \\
(0.171)\end{array}$ & $\begin{array}{r}0.188 \\
(0.127)\end{array}$ & $\begin{array}{l}-0.265 * * \\
(0.120)\end{array}$ & $\begin{array}{l}-0.948 * \\
(0.545)\end{array}$ & $\begin{array}{r}-0.023 \\
(0.055)\end{array}$ & $\begin{array}{c}0.194 * \\
(0.103)\end{array}$ & $\begin{array}{r}-0.114 \\
(0.081)\end{array}$ & $\begin{array}{r}-0.445 \\
(0.366)\end{array}$ \\
\hline Age mig. 9-11 & $\begin{array}{r}0.182 \\
(0.134)\end{array}$ & $\begin{array}{l}0.279 * * \\
(0.139)\end{array}$ & $\begin{array}{l}-0.117 * \\
(0.065)\end{array}$ & $\begin{array}{r}-0.811 \\
(0.574)\end{array}$ & $\begin{array}{c}-0.037 \\
(0.086)\end{array}$ & $\begin{array}{l}0.255 * * \\
(0.102)\end{array}$ & $\begin{array}{l}-0.136 * \\
(0.075)\end{array}$ & $\begin{array}{l}-0.718 * \\
(0.381)\end{array}$ \\
\hline Age mig. 12-14 & $\begin{array}{r}0.178 \\
(0.159)\end{array}$ & $\begin{array}{l}0.299 * * \\
(0.143)\end{array}$ & $\begin{array}{l}-0.101 * \\
(0.060)\end{array}$ & $\begin{array}{l}-0.053 \\
(0.502)\end{array}$ & $\begin{array}{r}0.092 \\
(0.095)\end{array}$ & $\begin{array}{r}0.136 \\
(0.102)\end{array}$ & $\begin{array}{l}-0.160 * \\
(0.090)\end{array}$ & $\begin{array}{r}-0.691 \\
(0.457)\end{array}$ \\
\hline Age mig. 15-17 & $\begin{array}{l}0.617 * * * \\
(0.121)\end{array}$ & $\begin{array}{l}0.313 * * \\
(0.136)\end{array}$ & $\begin{array}{r}-0.072 \\
(0.052) \\
\end{array}$ & $\begin{array}{l}-1.699 * * * \\
(0.409)\end{array}$ & $\begin{array}{r}0.036 \\
(0.181) \\
\end{array}$ & $\begin{array}{r}0.004 \\
(0.159) \\
\end{array}$ & $\begin{array}{r}-0.155 \\
(0.100) \\
\end{array}$ & $\begin{array}{r}-0.556 \\
(0.564) \\
\end{array}$ \\
\hline F-Test p-value & $0.000 * * *$ & 0.363 & 0.439 & $0.000 * * *$ & 0.839 & $0.091 *$ & 0.654 & 0.566 \\
\hline
\end{tabular}

Note: Dependent variables as specified. Robust standard errors are in parentheses. Additional explanatory variables: female, firstborn, and a constant. In Panel $\mathrm{C}$ we do not control for a 2nd generation main effect because it constitutes the reference group. Number of females: 294, number of males: 359. Significance level: $*<0.1, * *<0.05, * * *<0.01$.

Source: SOEP (1984-2013), own calculations. 
Table A.5 Fixed Effects Estimation Results - Dependent Variables: Health Satisfaction, Language Skills, Life Satisfaction and Integration

\begin{tabular}{|c|c|c|c|c|c|}
\hline & Health & $\begin{array}{c}\text { Language } \\
\text { ability }\end{array}$ & $\begin{array}{c}\text { Life } \\
\text { satisfaction }\end{array}$ & German friends & Intention to stay \\
\hline \multicolumn{6}{|c|}{ Panel A: Linear age at migration indicator } \\
\hline Age mig./10 & $\begin{array}{r}0.904 \\
(0.717) \\
\end{array}$ & $\begin{array}{l}-0.522 * * \\
(0.234)\end{array}$ & $\begin{array}{r}0.222 \\
(0.658) \\
\end{array}$ & $\begin{array}{r}-0.042 \\
(0.088) \\
\end{array}$ & $\begin{array}{r}-0.057 \\
(0.219) \\
\end{array}$ \\
\hline \multicolumn{6}{|c|}{ Panel B: Quadratic age at migration indicators } \\
\hline Age mig./10 & $\begin{array}{r}1.110 \\
(1.240)\end{array}$ & $\begin{array}{r}-0.160 \\
(0.562)\end{array}$ & $\begin{array}{c}-0.554 \\
(1.239)\end{array}$ & $\begin{array}{r}0.280 \\
(0.183)\end{array}$ & $\begin{array}{r}-0.023 \\
(0.351)\end{array}$ \\
\hline Age mig. ${ }^{2} / 100$ & $\begin{array}{r}-0.122 \\
(0.571) \\
\end{array}$ & $\begin{array}{r}-0.210 \\
(0.304) \\
\end{array}$ & $\begin{array}{r}0.451 \\
(0.673) \\
\end{array}$ & $\begin{array}{l}-0.201 * \\
(0.118)\end{array}$ & $\begin{array}{r}-0.021 \\
(0.183) \\
\end{array}$ \\
\hline F-Test p-value & 0.452 & $0.073 *$ & 0.777 & 0.237 & 0.964 \\
\hline \multicolumn{6}{|c|}{ Panel C: Categorical age at migration indicators } \\
\hline Age mig. 3-5 & $\begin{array}{r}0.132 \\
(0.555)\end{array}$ & $\begin{array}{l}-0.311 * \\
(0.180)\end{array}$ & $\begin{array}{l}-0.779 * * \\
(0.392)\end{array}$ & $\begin{array}{r}0.009 \\
(0.032)\end{array}$ & $\begin{array}{c}0.202 * \\
(0.121)\end{array}$ \\
\hline Age mig. 6-8 & $\begin{array}{r}0.490 \\
(0.613)\end{array}$ & $\begin{array}{l}-0.362 * \\
(0.218)\end{array}$ & $\begin{array}{c}-0.684 \\
(0.490)\end{array}$ & $\begin{array}{r}0.047 \\
(0.068)\end{array}$ & $\begin{array}{r}0.183 \\
(0.165)\end{array}$ \\
\hline Age mig. 9-11 & $\begin{array}{r}1.005 \\
(0.725)\end{array}$ & $\begin{array}{l}-0.454 * \\
(0.265)\end{array}$ & $\begin{array}{r}-0.231 \\
(0.663)\end{array}$ & $\begin{array}{r}-0.002 \\
(0.086)\end{array}$ & $\begin{array}{r}0.092 \\
(0.196)\end{array}$ \\
\hline Age mig. 12-14 & $\begin{array}{r}1.011 \\
(0.891)\end{array}$ & $\begin{array}{l}-0.684 * * \\
(0.332)\end{array}$ & $\begin{array}{l}-0.177 \\
(0.745)\end{array}$ & $\begin{array}{r}-0.060 \\
(0.120)\end{array}$ & $\begin{array}{r}0.142 \\
(0.241)\end{array}$ \\
\hline Age mig. 15-17 & $\begin{array}{l}1.697 * \\
(0.938) \\
\end{array}$ & $\begin{array}{l}-0.997 * * \\
(0.393)\end{array}$ & $\begin{array}{r}0.007 \\
(0.967) \\
\end{array}$ & $\begin{array}{r}-0.156 \\
(0.162) \\
\end{array}$ & $\begin{array}{r}0.261 \\
(0.322) \\
\end{array}$ \\
\hline F-Test p-value & 0.385 & 0.218 & 0.233 & 0.167 & 0.493 \\
\hline $\mathrm{N}$ & 345 & 302 & 348 & 244 & 298 \\
\hline
\end{tabular}

Note: Dependent variables as specified. Robust standard errors are in parentheses. Language skills: 5 high, 1 low). Additional explanatory variables: female, firstborn, year of immigration, and a constant. Significance level: $*<0.1, * *<0.05, * * *<0.01$.

Source: SOEP (1984-2013), own calculations. 
Table A.6 Fixed Effects Estimation Results $-1^{\text {st }}$ and $2^{\text {nd }}$ Generation, by Gender

\begin{tabular}{lcccc}
\hline & $\begin{array}{c}\text { No sec. } \\
\text { degree }\end{array}$ & $\begin{array}{c}\text { Up to lower } \\
\text { sec. degree }\end{array}$ & $\begin{array}{c}\text { Upper sec. } \\
\text { degree }\end{array}$ & $\begin{array}{c}\text { Years of } \\
\text { education }\end{array}$ \\
\hline Panel A: Line ar age at migration indicator \\
F test p-value females & $0.003 * * *$ & $0.074 *$ & $0.090 *$ & $0.000 * * *$ \\
F test p-value males & $0.029 * *$ & 0.164 & 0.980 & $0.075 *$ \\
\hline
\end{tabular}

\section{Panel B: Quadratic age at migration indicators}

\begin{tabular}{lllll} 
F test P-value females & $0.017 * *$ & $0.033 * *$ & 0.177 & $0.001 * * *$ \\
F test P-value males & $0.092 *$ & $0.019 * *$ & 0.736 & 0.114 \\
\hline
\end{tabular}

\section{Panel C: Categorical age at migration indicators}

\begin{tabular}{lllll} 
F test p-value females & $0.020 * *$ & $0.022 * *$ & $0.041 * *$ & $0.000 * * *$ \\
F test p-value males & 0.414 & $0.022 * *$ & 0.959 & 0.555 \\
\hline
\end{tabular}

Note: The table presents p-values for F-Tests of the hypothesis that all age at migration indicators are jointly insignificant. Dependent variables as specified. Explanatory variables: Age at migration*male, age at migration*female, female, firstborn, and a constant. Number of male observations: 534, number of female observations: 472. Significance level: $*<0.1, * *<0.05, * * *<0.01$.

Source: SOEP (1984-2013), own calculations. 
Table A.7 Fixed Effects Estimation Results - First and Second Generation Controlling for Parental Time since Migration at Birth

\begin{tabular}{|c|c|c|c|c|}
\hline & $\begin{array}{c}\text { No sec. } \\
\text { degree }\end{array}$ & $\begin{array}{l}\text { Up to lower } \\
\text { sec. degree }\end{array}$ & $\begin{array}{c}\text { Upper sec. } \\
\text { degree }\end{array}$ & $\begin{array}{r}\text { Years of } \\
\text { education }\end{array}$ \\
\hline \multicolumn{5}{|c|}{ Panel A: Linear age at migration indicator } \\
\hline Age mig./10 & $\begin{array}{l}0.116 \text { *** } \\
(0.048)\end{array}$ & $\begin{array}{l}0.168 \text { *** } \\
(0.059)\end{array}$ & $\begin{array}{l}-0.049 * * \\
(0.036)\end{array}$ & $\begin{array}{l}-0.569 * * * \\
(0.209)\end{array}$ \\
\hline 2nd Generation & $\begin{array}{r}0.004 \\
(0.071)\end{array}$ & $\begin{array}{r}-0.000 \\
(0.078)\end{array}$ & $\begin{array}{r}0.015 \\
(0.045)\end{array}$ & $\begin{array}{r}0.032 \\
(0.314)\end{array}$ \\
\hline \multicolumn{5}{|c|}{ Panel B: Quadratic age at migration indicators } \\
\hline Age mig./10 & $\begin{array}{l}0.116 \text { ** } \\
(0.048)\end{array}$ & $\begin{array}{l}0.169 * * * \\
(0.059)\end{array}$ & $\begin{array}{r}-0.050 \\
(0.034)\end{array}$ & $\begin{array}{l}-0.592 \text { *** } \\
(0.203)\end{array}$ \\
\hline Age mig. ${ }^{2} / 100$ & $\begin{array}{r}0.029 \\
(0.024)\end{array}$ & $\begin{array}{r}0.004 \\
(0.027)\end{array}$ & $\begin{array}{r}-0.001 \\
(0.022)\end{array}$ & $\begin{array}{r}-0.148 \\
(0.106)\end{array}$ \\
\hline 2nd Generation & $\begin{array}{r}0.011 \\
(0.072) \\
\end{array}$ & $\begin{array}{r}0.001 \\
(0.078) \\
\end{array}$ & $\begin{array}{r}0.014 \\
(0.044) \\
\end{array}$ & $\begin{array}{r}-0.006 \\
(0.313) \\
\end{array}$ \\
\hline F test p-value & $0.052 *$ & $0.017 * *$ & 0.187 & $0.006 * * *$ \\
\hline \multicolumn{5}{|c|}{ Panel C: Categorical age at migration indicators } \\
\hline Pre-birth maternal stay $19-27$ & $\begin{array}{r}0.082 \\
(0.120)\end{array}$ & $\begin{array}{r}0.012 \\
(0.135)\end{array}$ & $\begin{array}{r}-0.068 \\
(0.173)\end{array}$ & $\begin{array}{r}-0.286 \\
(0.775)\end{array}$ \\
\hline Pre-birth maternal stay $16-18$ & $\begin{array}{l}-0.183 * \\
(0.110)\end{array}$ & $\begin{array}{l}-0.338 * * \\
(0.152)\end{array}$ & $\begin{array}{r}0.081 \\
(0.167)\end{array}$ & $\begin{array}{r}0.319 \\
(0.646)\end{array}$ \\
\hline Pre-birth maternal stay $13-15$ & $\begin{array}{l}-0.221 * * \\
(0.087)\end{array}$ & $\begin{array}{l}-0.288 * * \\
(0.120)\end{array}$ & $\begin{array}{r}0.194 \\
(0.126)\end{array}$ & $\begin{array}{c}1.006 * \\
(0.547)\end{array}$ \\
\hline Pre-birth maternal stay $10-12$ & $\begin{array}{r}-0.082 \\
(0.081)\end{array}$ & $\begin{array}{l}-0.263 * * \\
(0.105)\end{array}$ & $\begin{array}{r}0.006 \\
(0.071)\end{array}$ & $\begin{array}{r}0.303 \\
(0.400)\end{array}$ \\
\hline Pre-birth maternal stay 7-9 & $\begin{array}{r}-0.040 \\
(0.076)\end{array}$ & $\begin{array}{l}-0.221 * * * \\
(0.083)\end{array}$ & $\begin{array}{r}0.018 \\
(0.067)\end{array}$ & $\begin{array}{r}0.209 \\
(0.413)\end{array}$ \\
\hline Pre-birth maternal stay 4-6 & $\begin{array}{r}-0.024 \\
(0.066)\end{array}$ & $\begin{array}{l}-0.195 * * \\
(0.083)\end{array}$ & $\begin{array}{r}-0.012 \\
(0.062)\end{array}$ & $\begin{array}{r}0.044 \\
(0.346)\end{array}$ \\
\hline Pre-birth maternal stay 1-3 & $\begin{array}{r}-0.062 \\
(0.067)\end{array}$ & $\begin{array}{r}-0.002 \\
(0.065)\end{array}$ & $\begin{array}{l}-0.114^{* *} \\
(0.055)\end{array}$ & $\begin{array}{r}-0.154 \\
(0.304)\end{array}$ \\
\hline Age mig. 3-5 & $\begin{array}{r}0.079 \\
(0.060)\end{array}$ & $\begin{array}{r}0.049 \\
(0.072)\end{array}$ & $\begin{array}{l}-0.083 * * \\
(0.042)\end{array}$ & $\begin{array}{l}-0.544 * \\
(0.283)\end{array}$ \\
\hline Age mig. 6-8 & $\begin{array}{r}0.114 \\
(0.072)\end{array}$ & $\begin{array}{l}0.211 \text { ** } \\
(0.082)\end{array}$ & $\begin{array}{l}-0.152 * * * \\
(0.057)\end{array}$ & $\begin{array}{l}-0.987 * * * \\
(0.341)\end{array}$ \\
\hline Age mig. 9-11 & $\begin{array}{l}0.158 \text { ** } \\
(0.080)\end{array}$ & $\begin{array}{l}0.225 * * * \\
(0.086)\end{array}$ & $\begin{array}{l}-0.115 * * \\
(0.051)\end{array}$ & $\begin{array}{l}-1.183 \text { *** } \\
(0.340)\end{array}$ \\
\hline Age mig. 12-14 & $\begin{array}{r}0.137 \\
(0.092)\end{array}$ & $\begin{array}{l}0.205 * * \\
(0.098)\end{array}$ & $\begin{array}{l}-0.104 * \\
(0.055)\end{array}$ & $\begin{array}{l}-0.776 * * \\
(0.366)\end{array}$ \\
\hline Age mig. 15-17 & $\begin{array}{l}0.266 * * \\
(0.120) \\
\end{array}$ & $\begin{array}{c}0.217 * \\
(0.111) \\
\end{array}$ & $\begin{array}{l}-0.148 * * \\
(0.060)\end{array}$ & $\begin{array}{l}-1.560 * * * \\
(0.432)\end{array}$ \\
\hline F test $\mathrm{p}$-value-1st gen & 0.351 & $0.078 *$ & 0.104 & $0.001 * * *$ \\
\hline F test p-value-2nd gen & 0.164 & $0.027 * *$ & 0.126 & 0.395 \\
\hline
\end{tabular}

Note: Dependent variables as specified. Robust standard errors are in parentheses. For the second generation, age at migration is calculated by: birth year - year of migration of mother. Pre-birth maternal stay is calculated by: year of migration of mother - birth year. Additional explanatory variables: female, firstborn, and a constant. Number of observations: 811. Significance level: $*<0.1, * *<0.05, * * *<0.01$. Source: SOEP (1984-2013), own calculations. 
Table A.8 Fixed Effects Estimation Results - Controlling for Birth Order Fixed Effects

\begin{tabular}{|c|c|c|c|c|}
\hline & $\begin{array}{c}\text { No sec. } \\
\text { degree }\end{array}$ & $\begin{array}{l}\text { Up to lower } \\
\text { sec. degree }\end{array}$ & $\begin{array}{c}\text { Upper sec. } \\
\text { degree }\end{array}$ & $\begin{array}{c}\text { Years of } \\
\text { education }\end{array}$ \\
\hline \multicolumn{5}{|c|}{ Panel A: Linear age at migration indicator } \\
\hline \multirow[t]{2}{*}{ Age mig./10 } & 0.107 & $0.571 * * *$ & -0.048 & $-1.275 * *$ \\
\hline & $(0.148)$ & $(0.193)$ & $(0.076)$ & $(0.633)$ \\
\hline \multirow[t]{2}{*}{ Second-born } & 0.014 & $0.141 *$ & -0.029 & -0.323 \\
\hline & $(0.066)$ & $(0.075)$ & $(0.023)$ & $(0.237)$ \\
\hline \multirow[t]{2}{*}{ Third-born } & 0.038 & $0.321 * * *$ & -0.022 & -0.607 \\
\hline & $(0.109)$ & $(0.107)$ & $(0.045)$ & $(0.376)$ \\
\hline \multirow[t]{2}{*}{ Later-born } & -0.137 & $0.407 * *$ & -0.038 & -0.939 \\
\hline & $(0.158)$ & $(0.178)$ & $(0.054)$ & $(0.675)$ \\
\hline F-Test p-value - birth order & 0.428 & $0.017 * *$ & 0.561 & 0.413 \\
\hline \multicolumn{5}{|c|}{ Panel B: Quadratic age at migration indicators } \\
\hline \multirow[t]{2}{*}{ Age mig./10 } & 0.323 & $0.908 * * *$ & -0.027 & $-2.038 *$ \\
\hline & $(0.248)$ & $(0.293)$ & $(0.118)$ & $(1.072)$ \\
\hline \multirow[t]{2}{*}{ Age mig. ${ }^{2} / 100$} & -0.124 & -0.195 & -0.012 & 0.440 \\
\hline & $(0.106)$ & $(0.128)$ & $(0.044)$ & $(0.457)$ \\
\hline \multirow[t]{2}{*}{ Second-born } & 0.014 & $0.140 *$ & -0.029 & -0.322 \\
\hline & $(0.067)$ & $(0.075)$ & $(0.023)$ & $(0.238)$ \\
\hline \multirow[t]{2}{*}{ Third-born } & 0.032 & $0.311 * * *$ & -0.022 & -0.583 \\
\hline & $(0.109)$ & $(0.105)$ & $(0.045)$ & $(0.373)$ \\
\hline \multirow[t]{2}{*}{ Later-born } & -0.125 & $0.426 * *$ & -0.037 & -0.981 \\
\hline & $(0.157)$ & $(0.178)$ & $(0.055)$ & $(0.670)$ \\
\hline F-Test p-value - AAM & 0.420 & $0.005 * * *$ & 0.762 & 0.104 \\
\hline F-Test p-value - birth order & 0.495 & $0.019 * *$ & 0.626 & 0.418 \\
\hline \multicolumn{5}{|c|}{ Panel C: Categorical age at migration indicators } \\
\hline \multirow[t]{2}{*}{ Age mig. 3-5 } & $0.188 * *$ & $0.226 * *$ & $-0.096 *$ & $-0.736 * *$ \\
\hline & $(0.083)$ & $(0.090)$ & $(0.049)$ & $(0.334)$ \\
\hline \multirow[t]{2}{*}{ Age mig. 6-8 } & $0.266 * *$ & $0.513 * * *$ & -0.121 & $-1.324 * * *$ \\
\hline & $(0.111)$ & $(0.129)$ & $(0.074)$ & $(0.477)$ \\
\hline \multirow[t]{2}{*}{ Age mig. 9-11 } & $0.304 * *$ & $0.675 * * *$ & -0.144 & $-1.810 * * *$ \\
\hline & $(0.135)$ & $(0.163)$ & $(0.093)$ & $(0.585)$ \\
\hline \multirow[t]{2}{*}{ Age mig. 12-14 } & $0.317 *$ & $0.819 * * *$ & -0.165 & $-1.724 * *$ \\
\hline & $(0.165)$ & $(0.190)$ & $(0.101)$ & $(0.679)$ \\
\hline \multirow[t]{2}{*}{ Age mig. 15-17 } & $0.425 * *$ & $0.964 * * *$ & $-0.237 *$ & $-2.659 * * *$ \\
\hline & $(0.194)$ & $(0.249)$ & $(0.124)$ & $(0.840)$ \\
\hline \multirow[t]{2}{*}{ Second-born } & 0.053 & $0.164 * *$ & $-0.054 * *$ & $-0.421 *$ \\
\hline & $(0.059)$ & $(0.070)$ & $(0.026)$ & $(0.228)$ \\
\hline \multirow[t]{2}{*}{ Third-born } & 0.081 & $0.331 * * *$ & -0.054 & $-0.682 * *$ \\
\hline & $(0.089)$ & $(0.098)$ & $(0.046)$ & $(0.332)$ \\
\hline \multirow[t]{2}{*}{ Later-born } & -0.041 & $0.464 * * *$ & -0.098 & $-1.101 *$ \\
\hline & $(0.147)$ & $(0.150)$ & $(0.059)$ & $(0.639)$ \\
\hline F-Test p-value - AAM & 0.239 & 0.002 & 0.280 & 0.018 \\
\hline F-Test p-value - birth order & 0.486 & $0.007 * * *$ & 0.216 & 0.182 \\
\hline
\end{tabular}

Note: Dependent variables as specified. Robust standard errors are in parentheses. Additional explanatory variables: female, year of immigration, and a constant. Number of observations: 348 . Significance level: $*<0.1, * *<0.05, * * *<0.01$.

Source: SOEP (1984-2013), own calculations. 
Table A.9 Fixed Effects Estimation Results - Omitting Observations with Education from Abroad

\begin{tabular}{lcccc}
\hline & $\begin{array}{c}\text { No sec. } \\
\text { degree }\end{array}$ & $\begin{array}{c}\text { Up to lower } \\
\text { sec. degree }\end{array}$ & $\begin{array}{c}\text { Upper sec. } \\
\text { degree }\end{array}$ & $\begin{array}{c}\text { Years of } \\
\text { education }\end{array}$ \\
\hline Panel A: Line ar age at migration indicator & & & \\
Age mig./10 & $0.291^{* *}$ & $0.414^{* *}$ & -0.056 & $-1.096 *$ \\
& $(0.131)$ & $(0.169)$ & $(0.046)$ & $(0.562)$ \\
\hline
\end{tabular}

\section{Panel B: Quadratic age at migration indicators}

\begin{tabular}{lcccc} 
Age mig./10 & 0.643 & $0.744 * *$ & -0.034 & -1.625 \\
& $(0.261)$ & $(0.297)$ & $(0.105)$ & $(1.090)$ \\
Age mig. ${ }^{2} / 100$ & -0.208 & -0.195 & -0.013 & 0.313 \\
& $(0.115)$ & $(0.148)$ & $(0.049)$ & $(0.486)$ \\
\hline F-Test p-value & $0.042 * *$ & $0.023 * *$ & 0.221 & 0.151 \\
\hline \multicolumn{5}{c}{ Panel C: Categorical age at migration indicators } \\
Age mig. 3-5 & $0.211^{* * *}$ & $0.193 * *$ & $-0.094 *$ & -0.563 \\
& $(0.080)$ & $(0.085)$ & $(0.050)$ & $(0.361)$ \\
Age mig. 6-8 & $0.317 * * *$ & $0.469 * * *$ & -0.115 & $-1.125 * *$ \\
& $(0.111)$ & $(0.132)$ & $(0.070)$ & $(0.536)$ \\
Age mig. 9-11 & $0.391 * * *$ & $0.547 * * *$ & $-0.135 *$ & $-1.348 * *$ \\
& $(0.134)$ & $(0.159)$ & $(0.076)$ & $(0.590)$ \\
Age mig. 12-14 & $0.494 * * *$ & $0.635 * * *$ & $-0.147 *$ & $-1.430 * *$ \\
& $(0.162)$ & $(0.185)$ & $(0.081)$ & $(0.674)$ \\
Age mig. 15-17 & $0.550 * * *$ & $0.794 * * *$ & $-0.231 * *$ & $-2.432 * * *$ \\
& $(0.193)$ & $(0.239)$ & $(0.098)$ & $(0.813)$ \\
\hline F-Test p-value & $0.065 *$ & $0.021 * *$ & 0.289 & $0.043 * *$ \\
\hline
\end{tabular}

Note: Dependent variables as specified. Robust standard errors are in parentheses. Additional explanatory variables: female, firstborn, year of immigration, and a constant. Number of observations: 290. Significance level: $*<0.1, * *<0.05, * * *<0.01$.

Source: SOEP (1984-2013), own calculations. 
Table A.10 Fixed Effects Estimation Results - Matching Siblings Based on Having the Same Mother

\begin{tabular}{lcccc}
\hline & $\begin{array}{c}\text { No sec. } \\
\text { degree }\end{array}$ & $\begin{array}{c}\text { Up to lower } \\
\text { sec. degree }\end{array}$ & $\begin{array}{c}\text { Upper sec. } \\
\text { degree }\end{array}$ & $\begin{array}{c}\text { Years of } \\
\text { education }\end{array}$ \\
\hline Panel A: Line ar age at migration indicator & & & \\
Age mig./10 & 0.028 & $0.274 *$ & -0.044 & -0.783 \\
& $(0.141)$ & $(0.151)$ & $(0.040)$ & $(0.522)$ \\
\hline
\end{tabular}

Panel B: Quadratic age at migration indicators

\begin{tabular}{lcccc} 
Age mig./10 & 0.218 & $0.647 * *$ & 0.037 & $-1.757 *$ \\
& $(0.274)$ & $(0.249)$ & $(0.107)$ & $(1.060)$ \\
Age mig. ${ }^{2} / 100$ & -0.118 & -0.232 & -0.050 & 0.605 \\
& $(0.114)$ & $(0.141)$ & $(0.057)$ & $(0.513)$ \\
\hline F-Test p-value & 0.578 & $0.031 * *$ & 0.284 & 0.222 \\
\hline \multirow{5}{*}{ Panel C: Categorical age at migration indicators } & & \\
Age mig. 3-5 & $0.162 *$ & $0.162 *$ & -0.041 & -0.551 \\
& $(0.097)$ & $(0.087)$ & $(0.057)$ & $(0.351)$ \\
Age mig. 6-8 & 0.205 & $0.380 * * *$ & -0.051 & $-1.013 * *$ \\
& $(0.126)$ & $(0.120)$ & $(0.071)$ & $(0.491)$ \\
Age mig. 9-11 & 0.182 & $0.417 * * *$ & -0.076 & $-1.239 * *$ \\
& $(0.147)$ & $(0.143)$ & $(0.071)$ & $(0.550)$ \\
Age mig. 12-14 & 0.251 & $0.502 * * *$ & -0.092 & $-1.173 *$ \\
& $(0.166)$ & $(0.171)$ & $(0.077)$ & $(0.621)$ \\
Age mig. 15-17 & 0.300 & $0.537 * *$ & $-0.167 *$ & $-1.866 * *$ \\
& $(0.201)$ & $(0.234)$ & $(0.088)$ & $(0.822)$ \\
\hline F-Test p-value & 0.540 & $0.046 * *$ & 0.354 & 0.216 \\
\hline
\end{tabular}

Note: Dependent variables as specified. Robust standard errors are in parentheses. Additional explanatory variables: female, firstborn, year of immigration, and a constant. Number of observations: 324. Significance level: $*<0.1, * *<0.05, * * *<0.01$.

Source: SOEP (1984-2013), own calculations. 
Table A.11 Fixed Effects Estimation Results - Adding Observations with Imputed Education Outcomes

\begin{tabular}{|c|c|c|c|c|}
\hline & $\begin{array}{c}\text { No sec. } \\
\text { degree }\end{array}$ & $\begin{array}{l}\text { Up to lower } \\
\text { sec. degree }\end{array}$ & $\begin{array}{c}\text { Upper sec. } \\
\text { degree }\end{array}$ & $\begin{array}{r}\begin{array}{r}\text { Years of } \\
\text { education }\end{array} \\
\end{array}$ \\
\hline \multicolumn{5}{|c|}{ Panel A: Linear age at migration indicator } \\
\hline Age mig./10 & $\begin{array}{l}0.190 * \\
(0.111)\end{array}$ & $\begin{array}{l}0.267 * \\
(0.145)\end{array}$ & $\begin{array}{r}-0.019 \\
(0.041) \\
\end{array}$ & $\begin{array}{r}-0.731 \\
(0.471) \\
\end{array}$ \\
\hline \multicolumn{5}{|c|}{ Panel B: Quadratic age at migration indicators } \\
\hline Age mig./10 & $\begin{array}{l}0.485 * * \\
(0.232)\end{array}$ & $\begin{array}{l}0.678 * * * \\
(0.247)\end{array}$ & $\begin{array}{r}-0.063 \\
(0.091)\end{array}$ & $\begin{array}{l}-1.945 * \\
(1.044)\end{array}$ \\
\hline Age mig. ${ }^{2} / 100$ & $\begin{array}{r}-0.018 \\
(0.011) \\
\end{array}$ & $\begin{array}{l}-0.024 * \\
(0.013)\end{array}$ & $\begin{array}{r}0.003 \\
(0.005) \\
\end{array}$ & $\begin{array}{r}0.072 \\
(0.051) \\
\end{array}$ \\
\hline F-Test p-value & 0.104 & 0.022 & 0.775 & 0.154 \\
\hline \multicolumn{5}{|c|}{ Panel C: Categorical age at migration indicators } \\
\hline Age mig. 3-5 & $\begin{array}{l}0.208 * * * \\
(0.074)\end{array}$ & $\begin{array}{l}0.181 * * \\
(0.079)\end{array}$ & $\begin{array}{l}-0.133 * * \\
(0.057)\end{array}$ & $\begin{array}{l}-0.818 * * \\
(0.364)\end{array}$ \\
\hline Age mig. 6-8 & $\begin{array}{l}0.292 \text { *** } \\
(0.101)\end{array}$ & $\begin{array}{l}0.409 * * * \\
(0.119)\end{array}$ & $\begin{array}{l}-0.134 * \\
(0.071)\end{array}$ & $\begin{array}{l}-1.321 * * \\
(0.507)\end{array}$ \\
\hline Age mig. 9-11 & $\begin{array}{l}0.364 \text { *** } \\
(0.118)\end{array}$ & $\begin{array}{l}0.479 \text { *** } \\
(0.138)\end{array}$ & $\begin{array}{l}-0.158 * * \\
(0.069)\end{array}$ & $\begin{array}{l}-1.706 \text { *** } \\
(0.549)\end{array}$ \\
\hline Age mig. $12-14$ & $\begin{array}{l}0.364 * * * \\
(0.138)\end{array}$ & $\begin{array}{l}0.532 * * * \\
(0.157)\end{array}$ & $\begin{array}{l}-0.153 * * \\
(0.071)\end{array}$ & $\begin{array}{l}-1.380 * * \\
(0.600)\end{array}$ \\
\hline Age mig. $15-17$ & $\begin{array}{l}0.478 \text { *** } \\
(0.174)\end{array}$ & $\begin{array}{l}0.605 * * * \\
(0.217)\end{array}$ & $\begin{array}{l}-0.209 * * \\
(0.085)\end{array}$ & $\begin{array}{l}-2.184 \text { *** } \\
(0.751)\end{array}$ \\
\hline F-Test p-value & 0.058 & 0.016 & 0.179 & 0.024 \\
\hline
\end{tabular}

Note: Dependent variables as specified. Robust standard errors are in parentheses. Additional explanatory variables: female, firstborn, year of immigration, and a constant. Number of observations: 358. Significance level: $*<0.1, * *<0.05, * * *<0.01$.

Source: SOEP (1984-2013), own calculations. 
Table A.12 Fixed Effects Estimation Results - Adding Observations with "Other" Degrees from the Home Country to the Sample

\begin{tabular}{lcccc}
\hline & $\begin{array}{c}\text { No sec. } \\
\text { degree }\end{array}$ & $\begin{array}{c}\text { Up to lower } \\
\text { sec. degree }\end{array}$ & $\begin{array}{c}\text { Upper sec. } \\
\text { degree }\end{array}$ & $\begin{array}{c}\text { Years of } \\
\text { education }\end{array}$ \\
\hline Panel A: Linear age at migration indicator & & & \\
Age mig./10 & 0.157 & $0.315 * *$ & -0.063 & -0.560 \\
& $(0.106)$ & $(0.144)$ & $(0.040)$ & $(0.457)$ \\
\hline
\end{tabular}

Panel B: Quadratic age at migration indicators

\begin{tabular}{|c|c|c|c|c|}
\hline Age mig./10 & $\begin{array}{l}0.524 \text { ** } \\
(0.223)\end{array}$ & $\begin{array}{c}0.491 * * \\
(0.223)\end{array}$ & $\begin{array}{r}0.007 \\
(0.080)\end{array}$ & $\begin{array}{r}-1.125 \\
(0.916)\end{array}$ \\
\hline Age mig. ${ }^{2} / 100$ & $\begin{array}{l}-0.212 * * \\
(0.103)\end{array}$ & $\begin{array}{r}-0.102 \\
(0.116) \\
\end{array}$ & $\begin{array}{r}-0.040 \\
(0.044)\end{array}$ & $\begin{array}{r}0.326 \\
(0.440) \\
\end{array}$ \\
\hline F-Test p-value & 0.066 & 0.042 & 0.230 & 0.382 \\
\hline
\end{tabular}

Panel C: Categorical age at migration indicators

Age mig. 3-5

$0.210 * * *$

$0.169 * *$

$-0.085 *$

$-0.598 *$

(0.075)

(0.081)

(0.046)

(0.340)

Age mig. 6-8

$0.302 * * *$

$0.397 * * *$

$-0.103 *$

$-0.925 *$

Age mig. 9-11

(0.101)

(0.117)

(0.061)

(0.470)

$0.353 * * *$

0.422 ***

$-0.113 *$

-1.215 **

(0.114)

(0.136)

(0.064)

(0.504)

Age mig. 12-14

$0.367 * * *$

0.558 ***

$-0.141 * *$

$-0.985 *$

(0.137)

(0.155)

(0.069)

(0.576)

Age mig. 15-17

0.417 **

$0.674 * * *$

$-0.215 * *$

-1.548 **

F-Test p-value

$(0.167)$

$(0.208)$

(0.087)

(0.726)

Note: Dependent variables as specified. We assumed that the immigrants with "other" degrees had the equivalent of a lower secondary school degree; we assigned 10 years of education in these cases.

Robust standard errors are in parentheses. Additional explanatory variables: female, firstborn, year of immigration, and a constant. Number of observations: 402. Significance level: $*<0.1, * *<0.05$, $* * *<0.01$.

Source: SOEP (1984-2013), own calculations. 